\title{
Avaliação Pós-Ocupação de Edificação Escolar: Proposta de Diretrizes para a Requalificação do Pátio Escolar
}

\author{
Mauricio Dallastra ${ }^{1}$; Morgana Alves de Jesus Fernandes ${ }^{2}$; \\ Luiz Eduardo Brescovit ${ }^{3}$; Bruna Lopes Costa ${ }^{4}$
}

\begin{abstract}
Resumo: O presente trabalho apresenta a Avaliação Pós-Ocupação de Edificação Escolar: Proposta de Diretrizes para a Requalificação do Pátio Escolar. A desarticulação das duas áreas do conhecimento - a arquitetura e a educação - mostram a necessidade de uma análise sobre a problemática resultante do caminho de oposição traçado até então. É possível fazer do pátio escolar um local de efetivação de sua função. A Avaliação PósOcupação é uma ferramenta imprescindível para este trabalho, tendo em vista seu contato direto com o usuário a fim de compreender melhor a rotina e a psicologia do local. É possível estabelecer diretrizes para que o pátio escolar possa ser adequado ao ensino e aprendizagem nas escolas, sendo este, em subsistema de espaços livres de utilização cotidiana e coletiva, e de importância referencial na concepção das escolas públicas. Deste modo, o objetivo geral da pesquisa é desenvolver diretrizes para a requalificação de pátios escolares por meio de análise das áreas externas do Centro Municipal de Ensino Fundamental Gentila Susin Muraro, localizado na zona urbana da cidade de Tangará da Serra - MT. Como estratégia metodológica, pesquisas bibliográficas, estudo de campo, sequenciados de APO, foram utilizados para a construção da pesquisa.
\end{abstract}

Palavras Chave: Avaliação Pós-Ocupação, Paisagismo, Pátio Escolar

\section{Post-occupation Evaluation of School Building: Proposal of Guidelines for the Requalification of the Schoolyard}

\begin{abstract}
This work presents a Post-Occupancy Evaluation of School Building: Proposed Guidelines for the Rehabilitation of the School Yard. The disarticulation of the two fields of knowledge - the architecture and education - show the need for an analysis of the problems arising from the way the opposition traced so far. You can make the schoolyard a place of realization of their function. The Post Occupancy Evaluation is an essential tool for this work, in view of its direct contact with the user in order to better understand the routine and the psychology of place. It is possible to establish guidelines for the schoolyard may be appropriate to teaching and learning in schools, this being in subsystem spaces of everyday use and collective, and referential importance in the design of public schools. Thus, the objective of the research is to develop guidelines for the redevelopment of schoolyards through analysis of external areas of the Municipal Center Elementary School Gentila Susin Muraro, located in the urban area of the city of Tangara da Serra - MT. Methodological strategy, library research, field study, sequenced PDB were used to construct the research.
\end{abstract}

Keywords: Post-Occupancy Evaluation, Landscaping, Patio School,

\footnotetext{
${ }^{1}$ Arquiteto e Urbanista graduado pela Universidade Paranaense, no ano de 2012 e especialista em Iluminação e Design de Interiores pelo Instituto de Pós Graduação IPOG no ano de 2016. Contato: mauriciodallastra@ hotmail.com.

${ }^{2}$ Arquiteta e Urbanista pela Universidade do Estado de Mato Grosso no ano de 2014.

${ }^{3}$ Professor graduado em Educação Física Bacharelado e Licenciatura pela Faculdade Assis Gurgacz no ano de 2009, com especialização em Educação Infantil e anos iniciais no ano de 2009, Pedagogo pela Faculdade FAEST, no ano de 2016.

${ }^{4}$ Arquiteta e Urbanista pela Universidade do Estado de Mato Grosso no ano de 2016. 


\title{
Introdução
}

As relações entre o ambiente físico e o ser humano podem ser expressas através da área ambiente/comportamento, sendo esta multidisciplinar englobando a psicologia, arquitetura, paisagismo, sociologia, geografia, urbanismo etc. A aplicação deste conhecimento pode gerar a melhoria da qualidade de vida, por meio da educação ambiental e questões políticas. (MOORE et. al, 1985, apud, CERQUEIRA, 2006)

De acordo com Cerqueira, 2006, apud, Reis e Lay (1995),

\begin{abstract}
Avaliação Pós Ocupação - APO é uma alternativa metodológica amplamente utilizada por pesquisadores da área Ambiente - Comportamento, para avaliar o desempenho de ambientes construídos, e um instrumental capaz de, face a uma avaliação rigorosa e sistemática de ambientes construídos e ocupados por um certo período de tempo, aferir, por realimentação, os erros e acertos de projeto encontrados no objeto de estudo avaliado, a partir do ponto de vista do usuário. (p.10)
\end{abstract}

De acordos com Ornstein, a APO é uma das metodologias de avaliação do ambiente construído, que se difere de outras metodologias por levar em consideração além dos aspectos de produção do edifício, a avaliação pós-ocupação analisa também o ponto de vista do usuário, levando em consideração também aspectos de manutenção e uso. As metas da APO são:

- A busca por melhorias da qualidade de vida daqueles que usam um determinado ambiente seja por ação ou intervenção;

- Criar banco de dados, desenvolver conhecimento sistematizado sobre o ambiente e as relações ambiente comportamento. (ORNSTEIN, 1992)

A participação conjunta entre especialista e usuário no processo projetual e posteriormente nas avaliações sobre a percepção que este faz do ambiente criado, é o contexto que surge a Avaliação PósOcupação (APO), sendo esta uma pesquisa aplicada que realiza a comunicação entre o processo projetual - construtivo ocupacional, a fim de ir ao encontro dos anseios da comunidade. (SOUZA, 1997, apud, CERQUEIRA, 2006).

O controle da qualidade do ambiente construído (seja edificações escolares ou não) ainda é recente, onde em sua maioria, os programas de qualidade existentes enfocam a execução e fabricação de materiais, buscando o aumento da produtividade da mão de obra, mesmo ocorrendo à maioria das falhas na etapa de projeto. Estudos que observem desde a produção dos edifícios, em sua etapa de projeto até seu processo de uso cotidiano, ainda são novos. (ROMERO 2003, apud, CERQUEIRA, 2006).

Segundo Ornstein (1992), "as pesquisas avaliativas, no campo das ciências sociais, objetivam coletar, analisar e interpretar sistematicamente informações a propósito da implementação e eficiência 
de quaisquer intervenções humanas, para otimizar condições sociais e comunitárias.” (p. 18). Ainda segundo Sheila, a avaliação do ambiente construído pode ocorrer de forma técnica envolvendo ensaios e medições in loco; e/ou comportamental, a partir do ponto de vista dos usuários.

Nos EUA e posteriormente nos países desenvolvidos iniciaram-se as primeiras pesquisas relacionadas ao ambiente e comportamento, por volta de 1950, e somente nos anos de 1970 estes estudos começaram a ser realizados nos países em desenvolvimento. A influência do ambiente sobre o comportamento humano foi o primeiro enfoque dado nas pesquisas, normalmente desenvolvidas por psicólogos. Os conjuntos habitacionais do período pós-guerra foram utilizados como objeto de estudo, tendo em vista seu desenvolvimento a partir de novos conceitos do Modernismo, onde a busca inicial era atender técnicas construtivas e ao uso do edifício para um usuário universal. As consequências deste novo modo de habitar puderam ser estudas a partir da correlação entre ambiente e usuário. Um exemplo deste estudo foi a pesquisa desenvolvida por Philippe Boudon em 1972, onde em seu livro Lived-in Architecture, avalia o conjunto habitacional Pessac, próximo a Bourdeaux, França, projetado por Le Corbusier na década de 20 (ORNSTEIN, 1992).

A partir da década de 90, os aspectos técnicos dos edifícios passaram a receber maior enfoque nas pesquisas de avaliação pós-ocupação, onde a gestão de projeto e o controle de qualidade passaram a fazer parte do contexto da construção civil. Nos países europeus e nos EUA, a aplicação de um controle de qualidade garante a certificação de alguns edifícios.

No Brasil, a APO surge com trabalho de Del Carlo e Mota (1975), sendo seguido por trabalhos realizados posteriormente na Faculdade de Arquitetura e Urbanismo da Universidade de São Paulo. Atualmente, pesquisas vêm sendo realizadas nas Universidades Federais do Rio de Janeiro (UFRJ), Pernambuco (UFP), Rio Grande do Sul (UFRGS), Santa Catarina (UFSC) e na Universidade Estadual de Campinas (UNICAMP).

As APO's devem fazer parte do desenvolvimento de projetos que gerem construções cada vez melhores, fazendo parte do processo de produção projetual de um escritório de arquitetura ou órgãos governamentais, responsáveis pela produção de edifícios públicos ou não.

As avaliações Pós-Ocupação em ambientes escolares englobam estudos quanto aos aspectos comportamentais e satisfação dos usuários, como os estudos realizados por Monteiro et. al 1993. Internacionalmente podem-se destacar os trabalhos de Preiser, Sanoff, Francis e de Taylor e Vlastos que abordam o projeto participativo de crianças e adolescentes, pais e professores. No Brasil Ornstein, Arteiro e Kowaltowski utilizam a APO nas questões práticas e metodológicas.

\section{Técnicas Desenvolvidas em APO}


De acordo com Ornstein (1992), as pesquisas de avaliação pós-ocupação podem ser classificadas segundo três categorias: indicativa ou de curto prazo, onde faz indicação dos principais aspectos positivos e negativos do objeto de estudo através de rápidas visitas exploratórias ao ambiente e entrevistas com usuários-chave; investigativa ou de médio prazo, trata-se do nível anterior, acrescido da explicitação de critérios referenciais de desempenho; diagnóstico ou de longo prazo, define detalhadamente critérios de desempenho e utiliza técnicas sofisticadas de medidas correlacionando características físicas com as respostas dos usuários, tendo-se em mente a estrutura organizacional da entidade, exigindo recursos bem maiores do que os utilizados nos níveis anteriores.

Estas três categorias podem ainda ser classificadas em seis níveis que se unem com a realidade brasileira, onde três deles correspondem a avaliações físicas realizadas por pesquisadores/consultores e o restante referem-se a APO considerando o ponto de vista técnico com o dos usuários.

As principais técnicas presentes em todas as etapas de uma APO são apresentadas a seguir, de acordo com os conceitos abordados por Ornstein (1992). O primeiro passo é a identificação das variáveis envolvidas nesse tipo de pesquisa, assim como as metodologias empregadas na definição do Estudo de Caso em função do tipo de abordagem pretendida.

Segundo Ornstein (1992), as variáveis envolvidas em uma APO podem ser dividas em cinco categorias, dependo do tipo de avaliação a ser feita. São elas:

Avaliação técnico-construtiva e de conforto ambiental: Realizada pela equipe de pesquisadores, essa visa o reconhecimento especializado do ambiente/estudo de caso, o qual fornecendo subsídios para a interpretação da avaliação do ponto de vista dos usuários (comportamental). As variáveis envolvidas na Avaliação Técnico-Construtiva, questões relacionadas espaciais e físicas do edifício, bem como, suas instalações elétricas e hidro sanitárias. Já as variáveis de conforto ambiental relacionam-se as questões de desempenho do ambiente.

Avaliação técnico-funcional: Corresponde à avaliação do projeto arquitetônico proposto originalmente e o construído. Trata-se fundamentalmente da avaliação realizada pelos pesquisadores quanto ao desempenho funcional dos espaços resultantes.

Avaliação técnico-econômica: Trata-se dos índices econômicos extraídos da produção (projeto de construção) e uso (uso, operação e manutenção) do ambiente construído que podem determinar parâmetros para se medir a eficiência do ambiente construído.

Avaliação técnico-estética: A fim de comparar formas, volumes, o belo, a questão do estilo e da percepção ambiental, do ponto de vista do avaliador-arquiteto e do usuário, esta variável é mais difícil de ser avaliada em países em desenvolvimento, onde as questões técnico-construtivas, funcionais e econômicas são o enfoque primeiro.

Avaliação comportamental: Esta pode ser considerada a variável básica da APO, já que lida com o ponto de vista de várias categorias ou estratos de usuários, onde sua analise ocorre a partir de 
procedimentos estatísticos compatíveis. No tratamento do comportamento humano, seja individual ou em grupo, leva-se em consideração aspectos culturais e psicossociais. Cabe ressaltar também que o ponto de vista dos usuários em uma determinada avaliação tem grande significância, já que as observações dos pesquisadores/arquitetos não podem ser unânimes.

A APO antes de qualquer coisa deve ser previamente formulada para que ocorra o levantamento adequado dos dados e que as metas estipuladas possam ser alcançadas dentro dos prazos previstos. Ornstein (1992) apresenta um fluxograma de atividades (figura 01) dividido nas etapas de: coleta e levantamento de dados, diagnóstico, recomendações para o ambiente - estudo de caso e insumos para novos projetos.

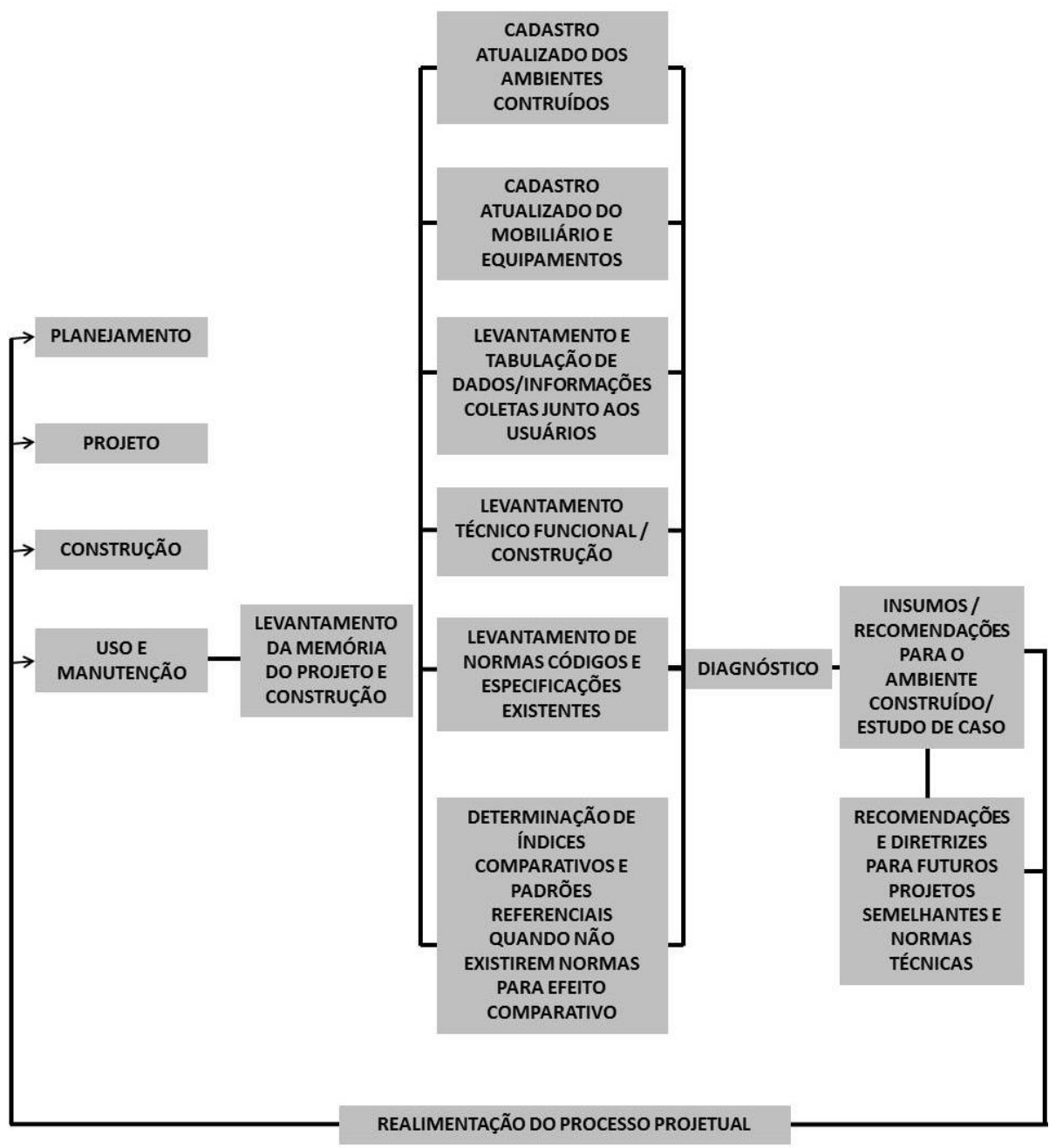

FIGURA 01: FLUXOGRAMA DE ATIVIDADES

Fonte: ORNSTEIN, 1992. Adaptado pelos Autores, 2013.

\section{APO em Edificações Escolares}


Os índices insatisfatórios de desenvolvimento dos alunos têm promovido discussões quanto ao ensino público no país. (WERTHEIN, 2010, apud, KOWALTOWSKI, 2011). Estudos comprovam a relação entre qualidade física da escola e desempenho dos alunos. (KOWALTOWSKI; GRAÇA; PETRECHE, 2007; TARALLI, 2004b, apud, KOWALTOWSKI, 2011). A Avaliação das edificações escolares se faz visível a partir desta importância que a arquitetura exerce sobre a qualidade do processo educacional. O dinamismo global, onde avanços tecnológicos e mudanças sociais influenciam no processo de desenvolvimento da arquitetura e sua qualidade final, ocorrendo também, em edifícios escolares. (KOWALTOWSKI, 2011).

De acordo com Pereira; Kowaltowski (2011), no Brasil os diversos estudos sobre o ambiente escolar, possuem como embasamento Avaliações Pós-Ocupação - APO. A avaliação técnica permitida pela APO tem maior difusão dentro da comunidade acadêmica, sendo considerada inviável pelos profissionais por ser um processo lento onde adotam a avaliação de maneira informal.

O processo de Avaliação Pós-Ocupação em escolas no Brasil abrangem questões como o projeto arquitetônico, conforto ambiental e avaliações das áreas externas das instituições. Grupos de pesquisa como o ProLugar (UFRJ) e o Qualidade e Desempenho no Ambiente Construído (FAUUSP) voltam suas pesquisas especialmente ao ambiente escolar.

No Estado de São Paulo a Fundação para o Desenvolvimento da Educação (FDE) coordena, avalia e distribui o processo projetual escolar no estado, com a orientação realizada aos escritórios terceirizados contratos, com a disponibilização do programa arquitetônico, levantamento topográfico, catálogos técnicos e lista de normas. A certificação de projetos quanto sustentabilidade, AQUA, também faz parte dos pré-requisitos estabelecidos pelo FDE. (PEREIRA, KOWALTOWSKI, 2011).

As escolas consideradas de alta qualidade receberam durante seu processo de projeto, avaliações antes da realização da obra, estando esta fase disposta a atividades como: análise, síntese, previsão, avaliação e decisão.

Quanto às técnicas de APO a serem aplicadas em escolas devem considerar faixa etária e capacidade de leitura. Questionários aplicados aos alunos podem corresponder a questões sobre conforto ambiental: ergonomia, funcionalidade, térmico, visual e acústico, para referencias quanto ao conforto da sala de aula. As escalas de avaliação podem compor: ótimo, bom, ruim, péssimo. Questionários aos alunos em alfabetização devem ser direcionados por desenhos.

Dentre os instrumentos e ferramentas, utilizados como técnicas de APO foram selecionadas sete exemplares que dentro da bibliografia estuda apresentam como produto final a visão do pesquisador e do usuário. São elas: Walkthrough ${ }^{5}$, Mapa Comportamental, Mapeamento Visual, Matriz de Descobertas e Recomendações, Poema dos Desejos (Wish Poem), Entrevista e Questionário.

${ }^{5}$ Palavra da língua inglesa que pode ser traduzida como passeio ou entrevista acompanhado. 
Walkthrough: Sendo muito utilizado na avaliação de desempenho do ambiente construído e na programação arquitetônica, este método de análise ordena simultaneamente a entrevista com a observação. Kevin Lynch em 1960 realizou a primeira Walkthrough a partir de uma experiência de passeio com entrevista no centro de Boston, aplicada a um grupo de voluntários. (ZEISEL 1981, apud, RHEIGANTZ et. al. 2009).

A facilidade e rapidez na aplicação tem difundido o uso deste método em APO's, já que através do percurso dialogando com o(s) usuário(s) do local, observações do pesquisador podem ser realizadas durante o trajeto, sendo complementadas com os comentários dos usuários sobre o local, conciliando o pensamento técnico com a experiência oriunda da vivencia local. Rheingantz (2007), apud, Machado et. al. (2008), afirma que desse modo "torna-se possível identificar questões relativas ao espaço e as atividades nele desempenhadas merecedoras de uma avaliação mais cuidadosa, bem como planejar apropriadamente os demais métodos e instrumentos a serem utilizados" (p. s/n)

Mapa Comportamental: Utilizado para o registro em planta do comportamento e atividades dos usuários de determinado ambiente, por um tempo também determinado. Seus objetivos são: organizar as atividades e localização das pessoas em determinado lugar; conferir a relação ambiente planejado x ambiente existente, e descrever como ocorre o uso do ambiente, analisando o tempo de permanência e percurso dos indivíduos. (RHEIGANTZ et. al. 2009). O instrumento pode ser utilizado de modo centrado no lugar (registrando as ações no local, por meio de desenhos pré-elaborados) ou centrado nos indivíduos (observa-se um grupo ou individuo durante um determinado tempo e percurso). Sua utilização permite apresentar as escolhas ambientais dos indivíduos, mas não caracteriza o porquê de tais escolhas, deste modo, deve ser complementado com entrevistas e outras técnicas que permitam a descrição das razões.

Mapeamento Visual: Permite o registro da opinião dos usuários sobre quesitos relacionados ao ambiente construído, por meio de plantas baixas ou plantas esquemáticas. Desenvolvido por Ross Thorme em 1991, tem como objetivo: constatar a territorialidade e apropriação; avaliar adequação do mobiliário e dos equipamentos existentes; constatar a opinião dos usuários quanto aos pontos positivos e negativos do ambiente analisado sendo registrado em plantas. (RHEIGANTZ et. al. 2009). O mapeamento visual possibilita avaliar a relação de identidade com o local, explicitando a interação homem e lugar, onde "esta relação forma um sentido de integração e pertencimento do usuário ao lugar". (RHEIGANTZ et. al. 2009, p. 50)

Matriz de Descobertas e Recomendações: Criada por Helena Rodrigues e Isabelle Soares, tendo como objetivo o destaque das principais descobertas de uma APO, podendo haver assim a visualização dos registros realizados em campo. Segundo Rheigantz et. al. 2009, "a principal contribuição da Matriz de Descobertas é possibilitar uma visão panorâmica e não fragmentada do 
ambiente a ser analisado, apontando as qualidades e os problemas, identificados por meio de uma APO” (p. 100).

Poema dos Desejos (Wish Poem): A descrição do usuário de um determinado local seja ela verbalmente ou por desenhos, com o enfoque sobre o que seria ou teria o ambiente ideal na percepção do usuário, é o que compreende o instrumento desenvolvido por Henry Sanoff. Este instrumento possibilita ao pesquisador identificar, de acordo com os usuários, "a construção do que seria a imagem ideal do ambiente analisado ou futuramente projetado". (DEL RIO et. al. 1999, apud, RHEIGANTZ et. al. 2009, p. 43). Dentro de pesquisas com abordagem multimétodos, o Poema de Desejos é aplicado com o intuito de conhecer as interações pessoa-ambiente, presente no imaginário dos usuários, sendo complemento de instrumentos como Walktrhough.

Entrevista: Realizada por relato verbal ou conversação, a entrevista é uma técnica presente na maioria das pesquisas das ciências sociais. Seus objetivos são descritos por Lakatos; Marconi 1991, apud, Rheigantz et. al. 2009 como: "averiguar "fatos", determinar opiniões sobre os "fatos", determinar sentimentos, descobrir planos de ação, conhecer conduta atual ou do passado, reconhecer motivos conscientes para opiniões, sentimentos, sistemas ou condutas" (p. 71). Este instrumento pode estar classificado em: entrevista estruturada ou padronizada (entrevistador segue um formulário ou roteiro); entrevista focalizada (específica sobre determinada experiência e efeitos); entrevista clínica (destaca-se na investigação sobre sentimentos ou questões pessoais vivenciadas pelo entrevistado); entrevista não estruturada ou não dirigidas (busca-se por parte do entrevistado, respostas espontâneas); painel (repetição de perguntas a um mesmo grupo) e entrevista por telefone (direcionada a uma pessoa ou por discagem aleatória).

Questionário: composto por várias perguntas direcionadas a um determinado tema ou problema os questionários devem ser respondidos sem a presença do pesquisador e por escrito. Quanto à análise dos resultados obtidos, dentro de avaliações sobre o desempenho, Rheigantz et. al. 2009 afirma que, "os resultados obtidos com a aplicação do questionário possibilita identificar o perfil dos respondentes e verificar sua opinião acerca dos atributos ambientais analisados" (p. 79). O questionário pode ser considerado um instrumento de fácil aplicação e baixo custo.

\section{Caracterização do Objeto de Estudo}

Em 1959 tem origem o município de Tangará da Serra, em terras de índios Paresí, a partir das frentes colonizadoras do interior. Na década de 60, a Sociedade Imobiliária de Tupã e Agricultura Ltda. (SITA) foi responsável pela colonização do município com a formação do loteamento urbano na Gleba Santa Fé. Por meio de divulgações em rádio, jornal e corretores a SITA atraía caravanas de 
imigrantes vindos de todo país, principalmente dos estados de Minas Gerais, Paraná e São Paulo. (OLIVEIRA, 2004).

Segundo dados Nepec (2011), a cidade localiza-se no sudoeste do estado de Mato Grosso, a 214 quilômetros da capital Cuiabá, com latitude 14 04' 38" Sul e longitude 5703' 45" Oeste. Tangará apresenta os distritos de Progresso, São Jorge, e São Joaquim, e limita-se com os municípios de: Campo Novo dos Parecis, Pontes e Lacerda, Barra do Bugres, Nova Olímpia, Santo Afonso, Nova Marilândia, Sapezal, Campos de Júlio, Denise, Diamantino, Reserva do Cabaçal e Conquista d' Oeste.

Em regimes de mutirão as pessoas que chegavam a cidade, se organizavam para resolver alguns problemas de ordem estrutural como construção de estradas, pontes e também escolas.

As escolas então eram construídas com material acessível no momento, sendo utilizado pau-apique ou madeira. O professor era aquele que na comunidade possuía um grau de escolaridade elevado, sendo estes geralmente leigos que possuíam até a quarta série do ensino primário. (OLIVEIRA, 2007)

Baseando-se em relatos orais, Oliveira (2007), afirma que,

(...) as famílias que chegaram a Tangará da Serra nos anos 60 do século XX começaram a mobilização para que seus filhos pudessem estudar, surgindo, assim, a primeira escola na localidade urbana, porém reconhecida oficialmente como rural "Escola Rural Mista de Instrução Primária de Tangará da Serra" criada em 04 de setembro de 1964. (OLIVEIRA, 2007, p. 02)

Somente em 29 de abril de 1970, esta escola rural mista vai ser transformada em Escola Reunida de Tangará da Serra, e elevada à categoria de Grupo Escolar de Tangará da Serra, permanecendo assim até 1975, quando se transforma em Escola Estadual de I Grau Emanuel Pinheiro. Em consonância com a criação do Grupo Escolar Tangará da Serra, são fundados também em 08 de agosto de 1971, o "Grupo Escolar Dr. Atibaia Antônio de Oliveira" e, em 29 de novembro de 1968 o "Ginásio Estadual de Tangará da Serra", unindo-se em 26 de outubro de 1976 dando assim origem a Escola Estadual 29 de Novembro. (OLIVEIRA, 2007)

\footnotetext{
A predominância inicial do modelo de escolas reunidas ocorreu, principalmente, em decorrência de seu baixo custo em relação ao grupo escolar, e por apresentar a vantagem de, ao agrupar as escolas isoladas, proporcionar maior controle do trabalho docente e economia com aluguéis, para o governo. (LOPES, 2006, apud, OLIVEIRA, 2007, p.08)
}

Atualmente a educação é um fator forte que caracteriza o município como polo de educação pública, a tabela abaixo apresenta a distribuição das instituições de ensino infantil, fundamental e médio com o número correspondente de alunos. 
TABELA 1: Rede PÚBliCA DE ENSINO FUndAMENTAL E MÉdio EM TANGARÁ DA SERRA - DADOS 2013

\begin{tabular}{|c|c|c|}
\hline Administração & Localização & Total de Alunos \\
\hline Estadual - 13 instituições & Urbana & 10.801 \\
\hline Estadual - 06 instituições & Rural & 1790 \\
\hline Total & & 12591 \\
Municipal - 23 instituições & Urbana & 9469 \\
\hline Municipal - 14 instituições & Rural (educação indígena) & 360 \\
\hline \multicolumn{2}{|c|}{ Total } & $\mathbf{9 8 2 9}$ \\
\hline \multicolumn{2}{|c|}{ Total de alunos matriculados na rede pública de ensino: $\mathbf{2 2 4 2 0}$} \\
\hline
\end{tabular}

Fonte: Secretaria Municipal de Educação 2013 / Assessoria Pedagógica 2013. Elaborado pelos Autores / 2013

O município é responsável pelo ensino fundamental, já o estado é responsável pelo ensino médio. Tangará da Serra conta ainda com 11 escolas particulares (educação infantil, ensino fundamental e médio) e 03 instituições de ensino superior: UNIC (Universidade de Cuiabá); ITEC (Instituição Tangaraense de Ensino e Cultura) e UNEMAT (Universidade do Estado de Mato Grosso).

Na tabela a seguir com dados fornecidos pelo IBGE 2010, pode-se observar o número de escolas na cidade de Tangará da Serra, e a relação com o número de instituições do Estado de Mato Grosso e do Brasil. É notório que o município está dentro dos níveis apresentados nas outras instancias da federação, tendo destaque para o ensino fundamental, com o maior número de atendimentos.

TABELA 2: NÚMERO DE ESCOLAS POR SÉRIE

\begin{tabular}{|c|c|c|c|}
\hline & & & \\
ATENDIMENTO & TANGARÁ DA SERRA & MATO GROSSO & BRASIL \\
\hline Pré-Escola & $30,1 \%$ & $14,5 \%$ & $9,1 \%$ \\
\hline Ensino Fundamental & $55,4 \%$ & $56,8 \%$ & $53,5 \%$ \\
\hline Ensino Médio & $14,5 \%$ & $28,7 \%$ & $37,4 \%$ \\
\hline
\end{tabular}

Fonte: IBGE, 2010. Adaptado pelos Autores, 2013.

O Centro Municipal de Ensino Gentila Susin Muraro localiza-se na Rua 70 A no 475-W Jardim San Diego no município de Tangará da Serra. Além do bairro em que está inserida, a escola atende a quatro bairros vizinhos, sendo eles: Jardim Monte Líbano, Jardim Vitória, Vila Esmeralda e Jardim Presidente.

A escolha pelo CME Gentila Susin Muraro como objeto de estudo ocorreu a partir dos critérios de pré-seleção das escolas de ensino fundamental com maior número de alunos nas series iniciais; posteriormente, a disposição de área livre em seu terreno para o desenvolvimento da proposta; a localidade em que a escola está inserida, sendo esta uma região pobre com altos índices de 
depredação da escola e a abertura e pré-disposição por parte do corpo técnico em participar da pesquisa e concretiza-la posteriormente a partir de um projeto pedagógico.

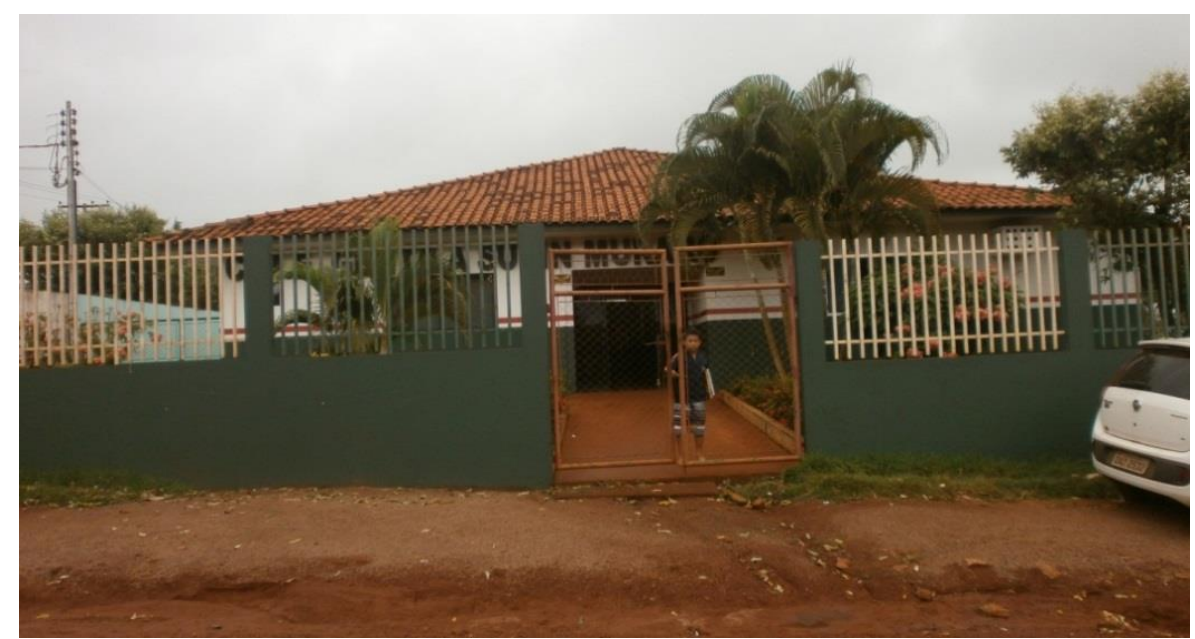

Figura 2: ENTRADA PRINCIPAL DO CME GENTILA SUSIN MURARO

Fonte: Acervo pessoal dos autores, 2013.

Abaixo a Tabela 3 descreve o número de alunos matriculados e turmas da escola Gentila Susin Muraro no ano de 2013, de acordo com a Secretaria Municipal de Educação e Cultura.

TABEla 3: NÚMERO DE ALUNOS E TURMAS

\begin{tabular}{|c|c|c|c|c|c|c|c|c|}
\hline \multirow{2}{*}{$\begin{array}{c}\text { CME } \\
\text { GENTILA } \\
\begin{array}{c}\text { SUSIN } \\
\text { MURARO }\end{array}\end{array}$} & \multicolumn{2}{|c|}{$\begin{array}{c}\text { EDUCAÇÃO } \\
\text { INFANTIL }\end{array}$} & \multicolumn{2}{c|}{$\begin{array}{c}\text { ENSINO } \\
\text { FUNDAMENTAL }\end{array}$} & \multicolumn{2}{c|}{ ANOS FINAIS } & \multicolumn{2}{c|}{ TOTAIS } \\
\cline { 2 - 8 } & Turmas & $\begin{array}{c}\mathrm{N}^{\mathrm{o}} \mathrm{De} \\
\text { Alunos }\end{array}$ & $\begin{array}{c}\text { Turmas } \\
\text { do } 1^{\circ} \text { ao } \\
5^{\circ} \text { Ano }\end{array}$ & $\begin{array}{c}\mathrm{N}^{\circ} \text { de } \\
\text { Alunos }\end{array}$ & $\begin{array}{c}\text { Turmas } \\
\text { do } 6^{\circ} \text { a } 8^{\circ} \\
\text { Série }\end{array}$ & $\begin{array}{c}\mathrm{N}^{\circ} \text { de } \\
\text { Alunos }\end{array}$ & $\begin{array}{c}\text { Total de } \\
\text { Turmas }\end{array}$ & $\begin{array}{c}\text { Total de } \\
\text { Alunos }\end{array}$ \\
\cline { 2 - 9 } & 06 & 137 & 13 & 339 & 06 & 171 & $\mathbf{2 5}$ & $\mathbf{6 4 7}$ \\
\hline
\end{tabular}

Fonte: Secretaria Municipal de Educação e Cultura, dados 2013. Adaptado pelos Autores, 2013.

O Centro Municipal de Ensino (CME) Gentila Susin Muraro foi fundado no ano de $2000 \mathrm{com}$ a desativação da antiga Escola do Ararão. A Lei 1537/00 de 19/04/00 criou o CME Gentila Susin Muraro autorizada pela portaria $n^{\circ} 002 / 06$ até 20/10/2010. O nome da escola é uma homenagem a mãe do prefeito no ano de fundação, Jaime Luis Muraro. (SEMEC, 2013)

A escola conta atualmente em sua estrutura física com 01 sala de direção e coordenação com 01 banheiro, 01 sala multifuncional, 01 secretaria, 01 sala dos professores com 02 banheiros, 12 salas de aula, 01 laboratório de informática, 01 refeitório coberto, 01 cozinha, 02 banheiros para alunos, 01 
biblioteca, 01 quadra poliesportiva coberta (figura 3) e 01 parquinho para educação infantil (figuras 4 a 9).

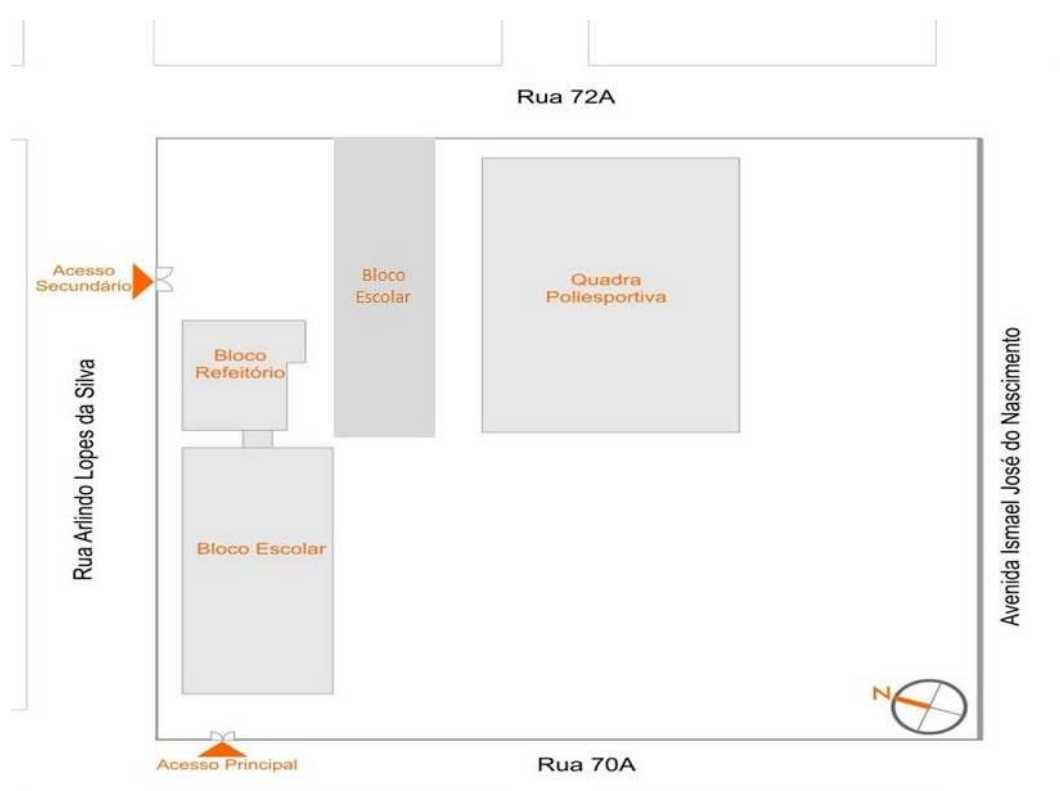

Figura 3: ImplantaÇão CME Gentila Susin Muraro

Fonte: Secretaria Municipal de Planejamento, 2003. Adaptado pelos Autores, 2013.

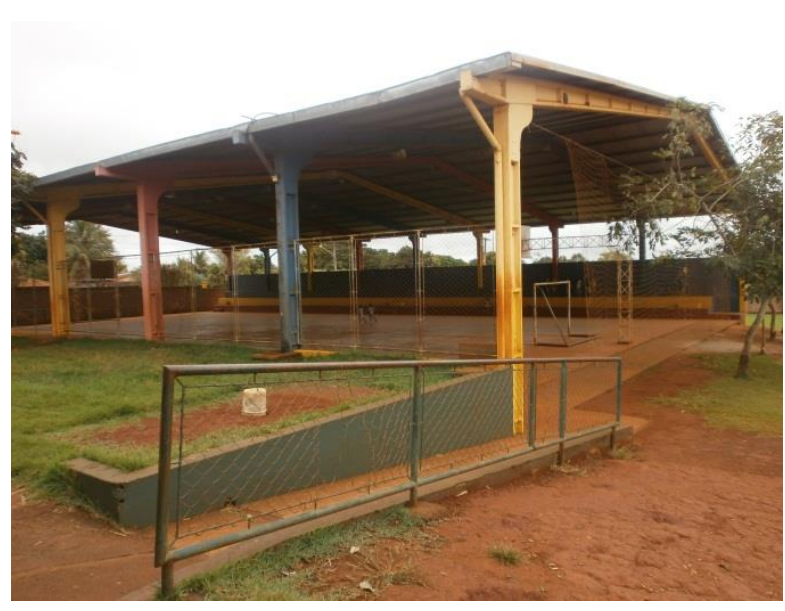

a

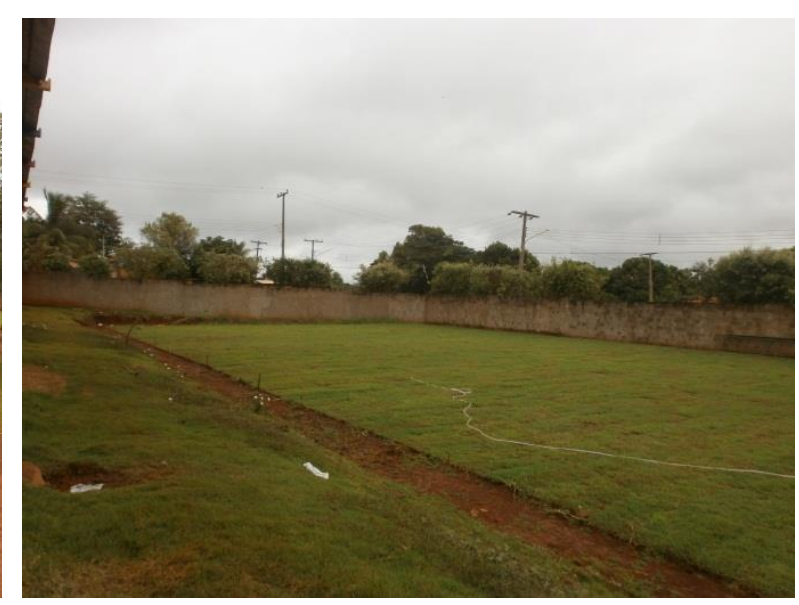

b

Figura 4: (A) Quadra Poliesportiva e (B) Campo de Futebol - CME Gentila Susin Muraro

Fonte: Acervo pessoal dos autores, 2013. 

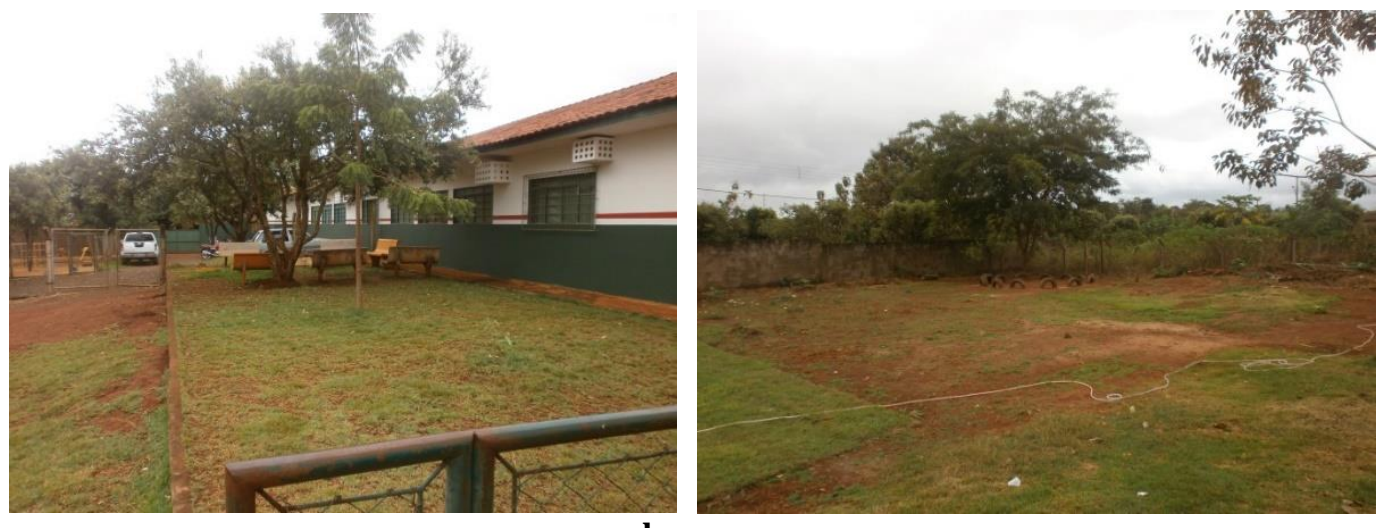

a b

Figura 5: (A) ÁREA livre ao lado das SAlas de Aula e (B) ANTigo PARQue de PNEUS Fonte: Acervo pessoal dos autores, 2013.

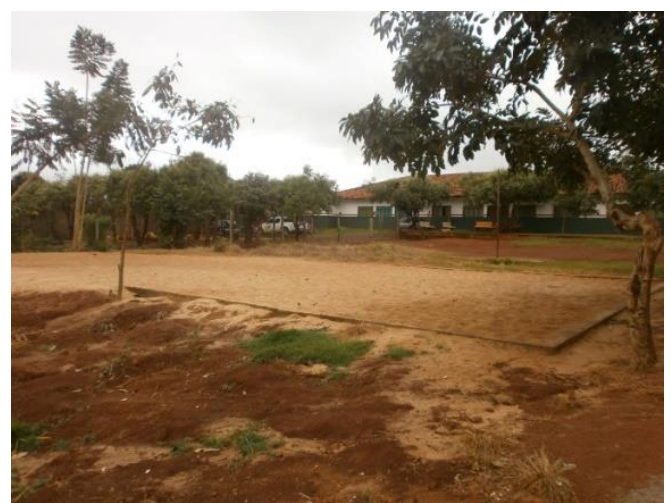

a

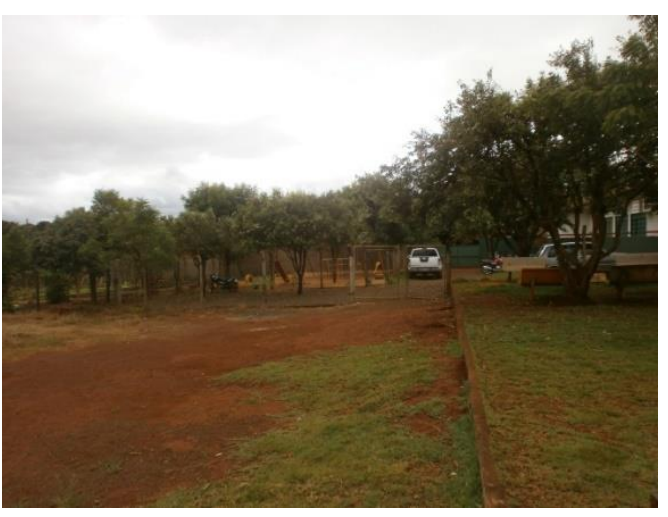

b

FIGURA 6: (A) QUADRA DE AREIA E (B) VISTA DO PARQUINHO

Fonte: Acervo pessoal dos autores, 2013.

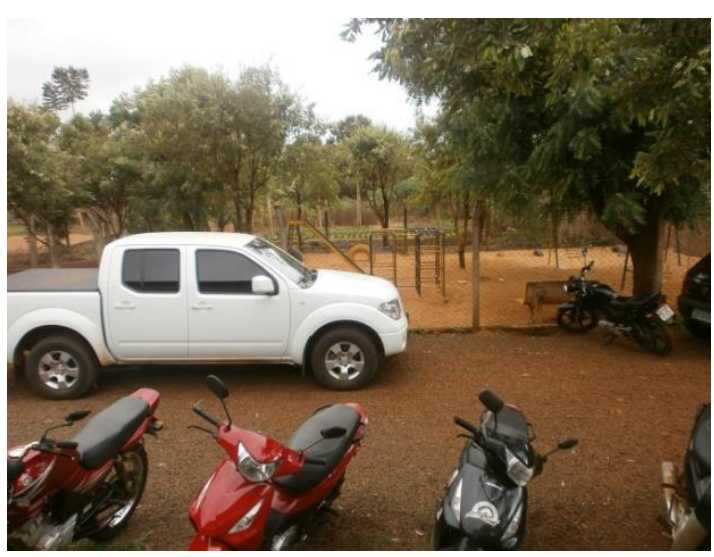

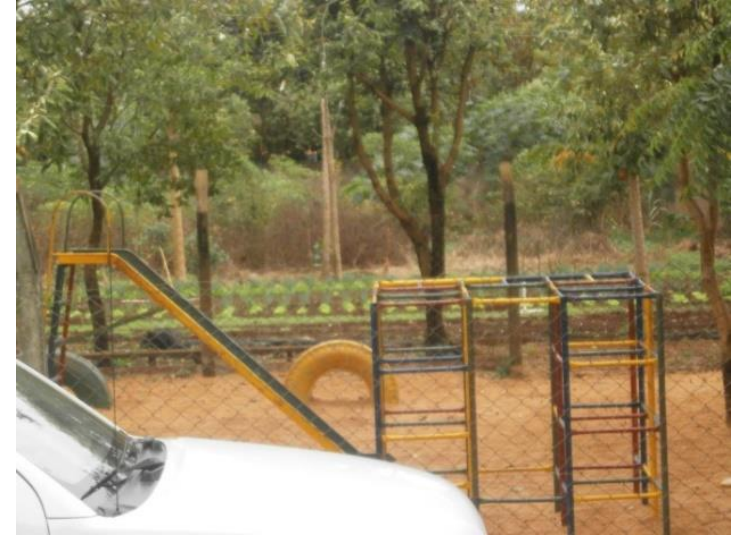

b

FIGURA 7: (A) ESTACIONAMENTO FUNCIONÁRIOS E (B) PARQUINHO E HORTA

Fonte: Acervo pessoal dos autores, 2013. 


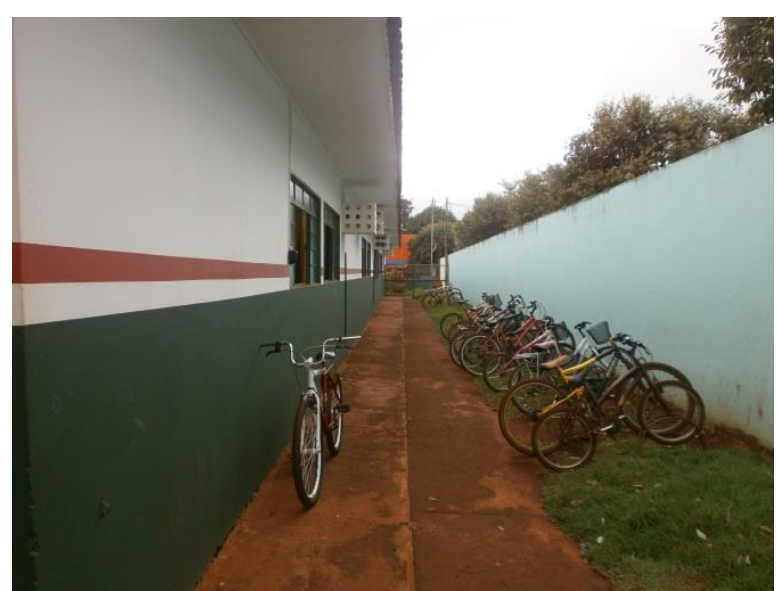

a

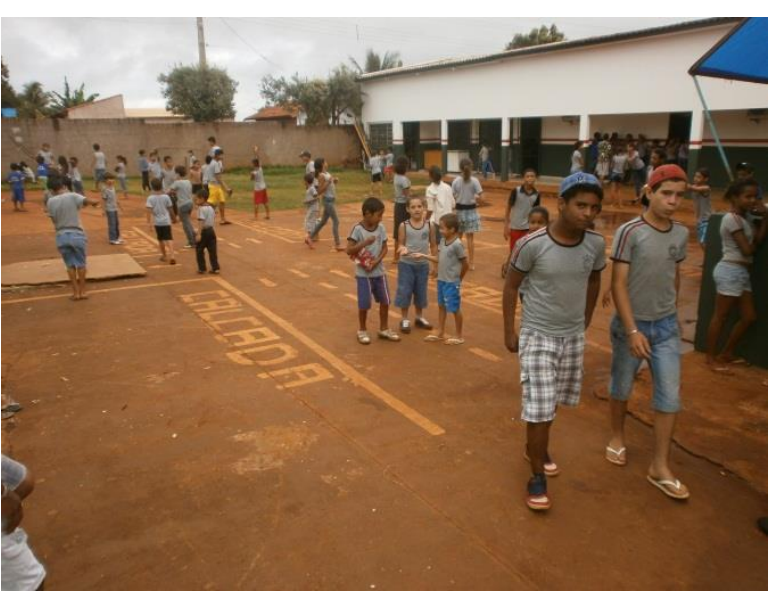

b

Figura 81: (A) Bicicletário e (B) PÁtio PAVIMENTADo DESCOBERTo

Fonte: Acervo pessoal dos autores, 2013.

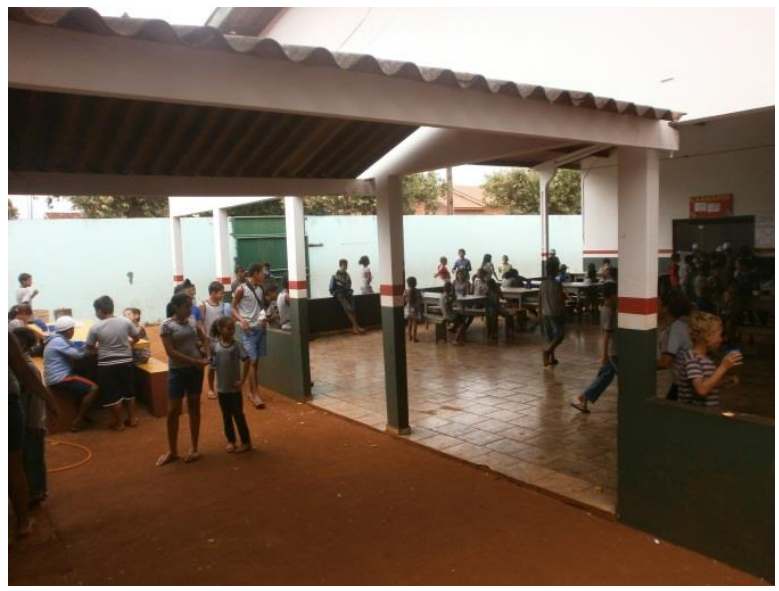

$\mathbf{a}$

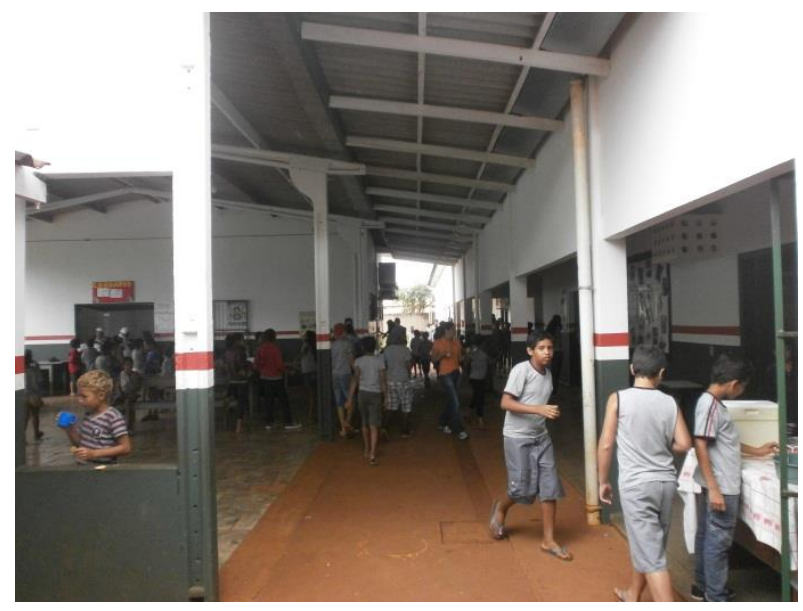

b

Figura 9: (A) REFEITÓRIO COBERTO E (B) CIRCULAÇÃo ENTRE SALAS E REFEITÓRIO

Fonte: Acervo pessoal dos autores, 2013.

O CME localiza-se em uma região com acentuados índices de vulnerabilidade social, pobreza e violência. De acordo com relatos da Diretora Professora Milria Lima Freire a escola é alvo de vandalismo, com a invasão de pessoas para consumo de drogas e depredação nos horários em que não há uso, já que a instituição não possui vigilante. Ainda segundo ela, a escola exerce seu papel de equipamento urbano não apenas para sua função junto à educação, mas é também utilizada como local para realização de missas e cultos da igreja católica e aos finais de semana as salas de aula se tornam centro catequético.

A escola faz parte do Programa Mais Educação - Ministério da Educação e Cultura, que tem como objetivo melhorar o ambiente escolar a partir de estudos realizados pelo Fundo das Nações Unidas para a Infância (UNICEF), utilizando recurso da Prova Brasil de 2005 e o Índice de Efeito 
Escola IEE onde por meio deste indicador é possível analisar a influência da escola na vida e no aprendizado do estudante, considerando informações socioeconômicas do município em que a escola se localiza. A participação da escola no Programa Mais Educação influenciou na proposta já que atividades são disponibilizadas durante todo o dia aos alunos, que passam cerca de 9 horas dentro da escola tendo aulas de reforço, atividades artísticas e pedagógicas.

O Fundo Nacional de Desenvolvimento da Educação (FNDE) tem como ferramenta o Levantamento da Situação Escolar (LSE) que permite apresentar as condições das escolas públicas de ensino radiografando questões como mobiliário, estrutura física, equipamentos e material escolar. $\mathrm{O}$ CME Gentila Susin Muraro passou por essa avaliação no ano de 2011, tendo como resultado a tabela abaixo:

Tabela 4: LeVantamento da SituaÇão Escolar - CME Gentila Susin Muraro

\begin{tabular}{|c|c|c|c|c|c|c|c|c|c|c|c|c|c|c|c|}
\hline Pontuação & I & II & III & IV & V & VI & VII & VIII & IX & X & XI & XII & XIII & XIV & XV \\
\hline LSE & 26 & 54 & 4 & 37 & 3 & 24.50 & 0 & 13.12 & 12.55 & 22 & 12 & 0 & 0 & 19.50 & 21 \\
\hline Max. & 52 & 72 & 60 & 52 & 23 & 49 & 40 & 40 & 40 & 40 & 46.5 & 0 & 33 & 47.7 & 54 \\
\hline
\end{tabular}

PGO 248.67 - PGM 649.20 - Índice PMFE 38.30\%

Indicador I: Cadastro da escola-Serviço

Indicador II: Características da escola - Infraestrutura Básica

Indicador III: Características da escola - Acessibilidade

Indicador IV: Características da escola - Avaliação do

Prédio

Indicador V: Características da escola - Entorno da escola

Indicador VI: Características físicas dos ambientes Utilização

Indicador VII: Características físicas dos ambientes -

Condições dos elementos da edificação

Indicador VIII: Características físicas dos ambientes -

Aspectos gerais

Indicador XI: Características físicas dos ambientes -

Componentes construtivos

Indicador X: Características físicas dos ambientes -

Acessibilidade

Indicador XI: Material didático

Indicador XII: Material didático - Atividades práticas

Indicador XIII: Material escolar

Indicador XIV: Equipamento

Indicador XV: Mobiliário

PGO: Pontuação Geral Obtida no LSE

PGM: Pontuação Geral Máxima da Escola

Índice PMFE: Índice dos Padrões Mínimos de Funcionamento da Escola

Fonte: Secretaria Municipal de Educação e Cultura - SMEC, adaptado pelos Autores, 2013.

Pode-se observar pelos resultados apresentados que a escola nos quesitos acessibilidade e entorno não obteve pontuação satisfatória de modo a ser considerada de qualidade para promoção do ensino. A avaliação realizada pelo LSE possui critérios rígidos que estão sendo remodelados, porém para a pesquisa em questão, é uma ferramenta importante quanto ao banco de dados técnicos referentes a escola. 


\section{Métodos}

Foram realizados: levantamento fotográfico e visita às instituições de ensino municipal préselecionadas; levantamento de arquivos junto ás secretarias municipais de Educação e Planejamento complementaram o processo de levantamento de dados.

A pesquisa-ação foi definida para o desenvolvimento deste estudo por possuir uma estrutura coletiva que envolve o pesquisador e os participantes do problema na captação de informações, agregando vários métodos ou técnicas de pesquisa. (THIOLLENT, (1998), apud, CERQUEIRA, 2001, p. 05).

Nesta dimensão coletiva a investigação na captação de informações ocorre por meio de entrevistas e questionários. Como técnicas de registro, têm-se como ferramenta as medições in loco, levantamento de campo e de arquivos.

A revisão bibliográfica serviu como ferramenta para a conceituação de toda pesquisa, mas principalmente da Avaliação Pós-Ocupação (APO), seu uso como ferramenta e enfoque na aplicação junto a edifícios escolares.

A APO foi utilizada devido a viabilidade e indicação para estudos em ambientes construídos que auxilia na avaliação do espaço em uso e considera a opinião do usuário na deteç̧ão de erros e acertos de projeto. Além disso, a APO proporcionará as diretrizes e sua aplicação na concepção da proposta de projeto paisagístico para o pátio escolar.

\section{Definição do Estudo de Caso}

Para se investigar uma determinada classe de edifícios escolares, por exemplo, a definição do estudo de caso deve ser feita a partir de critérios, já que essa etapa vai resultar do tipo de abordagem que se pretende fazer, ou de quais são os objetivos que se pretende alcançar.

Cerqueira (2006) apresenta três tipos de estudo de caso realizados por Bruyne (1982) sendo eles: no primeiro, estão aqueles de exploração que buscam descobrir problemáticas novas, renovar perspectivas existentes ou sugerir hipóteses fecundas, preparando assim o caminho para pesquisas posteriores. No segundo, têm-se os estudos descritivos, que buscam descrever toda a complexidade de um caso concreto sem absolutamente pretender obter o geral. No terceiro tipo, os estudos de caso que perseguem um objetivo prático e frequentemente utilitário, onde podem estabelecer o diagnóstico de uma organização ou a fazer sua avaliação, seja porque procuram prescrever uma terapêutica ou mudar uma organização. 
Nas Avaliações Pós-Ocupação é comum o estudo de caso detalhado em apenas um objeto, se enquadrando o segundo e o terceiro tipo apresentados por Bruyne, focando em apenas alguns aspectos do edifício (o conforto ambiental e a eficiência energética, ou manutenção e atos de vandalismo, etc.) a fim de um diagnóstico mais preciso sobre as relações que esses aspectos mantêm entre si; ou, até mesmo, a elaboração de uma metodologia detalhada para análise dos mesmos.

Ao se optar por apenas um estudo de caso é necessário a adoção de critério que observem que este será o exemplo representativo de todo o universo que se pretende estudar, onde suas conclusões podem ser utilizadas em edifícios semelhantes.

\section{Aplicação dos Métodos de Apo: Aspectos Físico-Espaciais}

Dentre as seis etapas da coleta de dados apresentadas Ornstein (1992), cabe destacar na aplicação das áreas externas o levantamento técnico-construtivo e de conforto ambiental e funcional são realizadas pela equipe técnica em conjunto com os usuários onde: o levantamento técnicoconstrutivo nada mais é do que a descrição do sistema construtivo adotado: solos e fundações, superestrutura, cobertura, drenagem de águas pluviais, impermeabilização, segurança contra incêndio, alvenarias, revestimentos, forros, pinturas, acabamentos, etc.; e o levantamento de conforto ambiental envolve a utilização de tecnologias ativas e passivas na obtenção do conforto térmico, luminoso, acústico e conservação de energia. Ainda se faz pertinente o levantamento de normas, códigos, especificações técnicas existentes, legislações a nível municipal, estadual e federal. Além da verificação da adequação do edifício as normas, esta etapa possibilita uma comparação dos critérios estabelecidos nesses instrumentos com o julgamento feito pelos usuários e pelos técnicos envolvidos na pesquisa.

\section{Aplicação dos Métodos de Apo: Perspectiva do Usuário}

Com base na revisão teórica apresentada foram definidos os métodos de APO a serem empregados respectivamente: entrevista, walkthrough, questionário, mapa comportamental, mapeamento visual, poema de desejos e matriz de descobertas e recomendações. A escolha pela APO é o método mais adequado para o desenvolvimento desta pesquisa.

Entrevista: No caso da pesquisa em questão, a entrevista foi aplicada junto ao corpo técnico da escola. Como primeiro contato com a intuição, a entrevista permitiu o descobrimento dos anseios e necessidades que da escola, onde também ocorrerá, a apresentação da proposta e indicações sobre melhores horários para visitas, turmas que podem receber a pesquisa. 
Walkthrough: O segundo método aplicado aconteceu com uma visita guiada junto a um responsável pela escola. Os dados serão coletados por meio de anotações, registros fotográficos, gravações ou desenhos. A ficha para aplicação do método (apêndice A) é composta de planta baixa e campo para anotação (em formato A4 para melhor manuseio). Por ser realizada por apenas um pesquisador, será realizada em duas etapas: uma para anotações, entrevista-percurso, outra para registro fotográfico.

Questionário: Aplicado junto aos alunos de $5^{\mathrm{a}}$ a $8^{\mathrm{a}}$ serie, devido a maior capacidade de compreensão no uso deste método. Será utilizado a fim de conduzir possíveis propostas para a escola, dando abertura para a formação do programa de necessidades da proposta. $\mathrm{O}$ apêndice $\mathrm{B}$ apresenta o questionário a ser aplicado.

Mapa comportamental: Este método de uso exclusivo da pesquisadora foi aplicado em horários de maior uso do pátio, com a observação em formulário (apêndice C). Estando como observadora do que ocorre, anotações referentes a maiores locais de uso, quantidade de alunos e faixa etária em determinado local, concentrações por idade e por sexo, foram registradas no formulário composto de cabeçalho para anotações como hora, data, clima, e planta baixa da escola.

Mapeamento visual: Este método foi aplicado com todas as turmas alfabetizadas, onde em formulário composto de fotos de local chave, observados durante o Mapeamento comportamental. Com a aplicação do mapeamento visual, pretende-se saber quais os ambientes de maior interesse dos alunos, quais ambientes menos lhe agradam e as sensações que estes locais passam de uma forma geral a comunidade escolar. O formulário aplicado (apêndice D) é composto de cabeçalho (instituição, data, hora, explicação da finalidade e propósito da pesquisa) e plantas baixas esquemáticas com layout, fotos e campo para anotações do respondente.

Poema dos Desejos: Este método é direcionado aos alunos ainda não alfabetizados, pela possibilidade de interpretação de seus anseios por meio desenhos. Com a ajuda dos professores, este método foi aplicado junto ao formulário (apêndice E) que contem cabeçalho de identificação, seguido da frase: "eu gostaria que o pátio da minha escola..." sendo respondido pelos alunos em forma de desenhos, que serão acompanhados para posterior compreensão.

Seleção Visual: Este método foi aplicado com todas as turmas alfabetizadas, onde em formulário (apêndice G) composto da planta da escola setorizada a fim de identificar valores e os significados agregados em cada pátio.

Matriz de Descobertas e Recomendações: Após a coleta de dados com a aplicação de todos os métodos apresentados acima, foi elaborada a Matriz de Descobertas e Recomendações, onde as informações coletadas foram selecionadas, classificadas e dispostas em tabelas e com comentários junto à planta baixa (apêndice F I e II). 
A Avaliação Pós-Ocupação, com a aplicação dos métodos selecionados, possibilita a identificação das diretrizes que serviram como base para a construção do programa de necessidades mais adequado para a requalificação do pátio da Escola Municipal Gentila Susin Muraro.

\section{Resultados e Discussão}

A população total do universo a ser estudado é de 610 alunos matriculados nos períodos matutino e vespertino. Levando em consideração que o instrumento Poema de Desejos foi aplicado apenas com as crianças ainda em alfabetização (Pré I ao $3^{\circ}$ ano) e os demais instrumentos questionário, seleção visual e mapeamento visual com os alunos em series mais avançadas $\left(4^{\circ}\right.$ ano ao $9^{\circ}$ ), tem-se o universo total dividido em duas partes para a definição de duas amostras, a primeira com 335 alunos e a segunda com 275 alunos.

Podendo definir o universo da amostra como finito, adotou-se para os parâmetros de erro e confiabilidade 10\% e 95\% respectivamente como indica Moreira (1984) onde são as porcentagens de confiança mais frequentemente adotadas em pesquisas sociais.

Sendo assim, adotou-se a fórmula apresentada por Richardson (1999) para o calculo das amostras, onde:

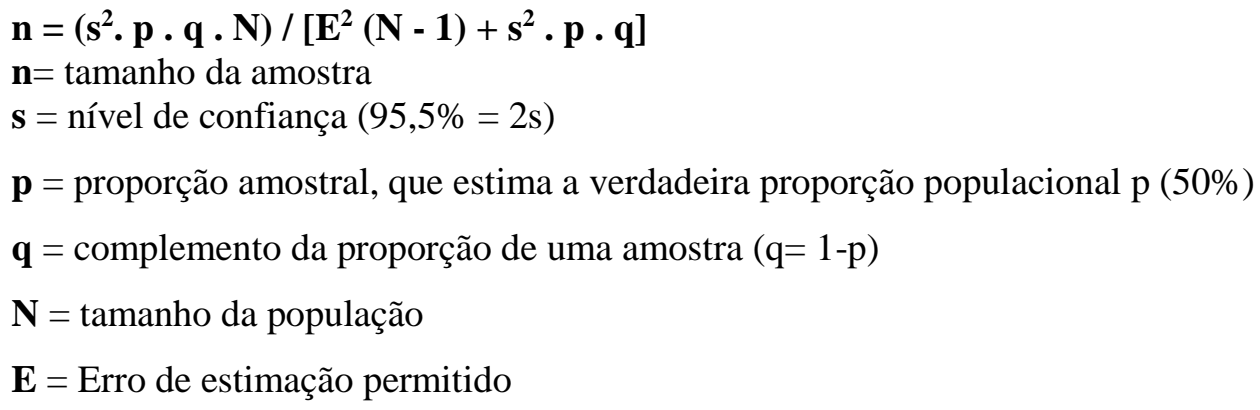


Já o cálculo para a definição da amostra para a aplicação dos métodos junto aos alunos do $4^{\circ}$ ao $9^{\circ}$ (275 alunos) obteve-se:

$$
\begin{aligned}
& \mathbf{n}=\left(\mathbf{s}^{2} \cdot \mathbf{p} \cdot \mathbf{q} \cdot \mathbf{N}\right) /\left[\mathbf{E}^{2}(\mathbf{N}-\mathbf{1})+\mathbf{s}^{2} \cdot \mathbf{p} \cdot \mathbf{q}\right] \\
& \mathbf{n}=\left(2^{2} \cdot 0,50 \cdot 0,50 \cdot 275\right) /\left[0,10 \cdot(275-1)+2^{2} \cdot 0,50 \cdot 0,50\right. \\
& \mathbf{n}=(4 \cdot 0,25 \cdot 275) / 0,01 \cdot(274)+4 \cdot 0,25 \\
& \mathbf{n}=275 / 2,74+1 \\
& \mathbf{n}=275 / 3,74 \\
& \mathbf{n}=73,32 \\
& \mathbf{n}=\text { Valor final arredondado para } \mathbf{7 4} \text { alunos }
\end{aligned}
$$

\section{Aplicação dos Métodos}

\section{Análise dos Pesquisadores}

Optou-se pelo Walkthrough como primeira abordagem a ser feita na escola a fim de se obter uma compreensão geral da rotina da escola e a relação dos usuários com a área externa.

O instrumento foi aplicado no dia 27 de agosto de 2013 às 09:00 horas na área externa da escola acompanhada pela Diretora Milriam Freire combinando à técnica de observação - olhar dos pesquisadores - com entrevista a partir do ponto de vista da Diretora. Durante a entrevista Milriam relatou os anseios do uso da área externa, problemas em determinados locais e assiduidade de uso. A aplicação do método também possibilitou a confecção da planta baixa "as built" da escola para atualização do arquivo disponibilizado pela Secretaria Municipal de Planejamento.

Durante a realização da walkthrough o registro dos dados ocorreu a partir do formulário (checklist) onde foram listados variados aspectos do ambiente que se pretendia observar. Junto às observações do formulário ocorreu também o registro fotográfico que auxilia na apresentação das observações realizadas pelos pesquisadores e pela diretora da escola.

O acesso à escola para funcionários, visitantes e estacionamento pode ser feito pela rua 70A, já o acesso dos alunos e carga e descarga ocorre pela entrada secundária localizada na Rua Arlindo Lopes da Silva. Todo o entorno da escola é composto por ruas sem pavimentação. Sua localização no bairro garante a proximidade com as Avenidas Brasil e Ismael José do Nascimento vias fundamentais ao município.

O entorno da escola (figura 10) possui uma boa arborização com a espécie Licania tomentosa (oiti), porém não conta com o calçamento e meio-fio. 


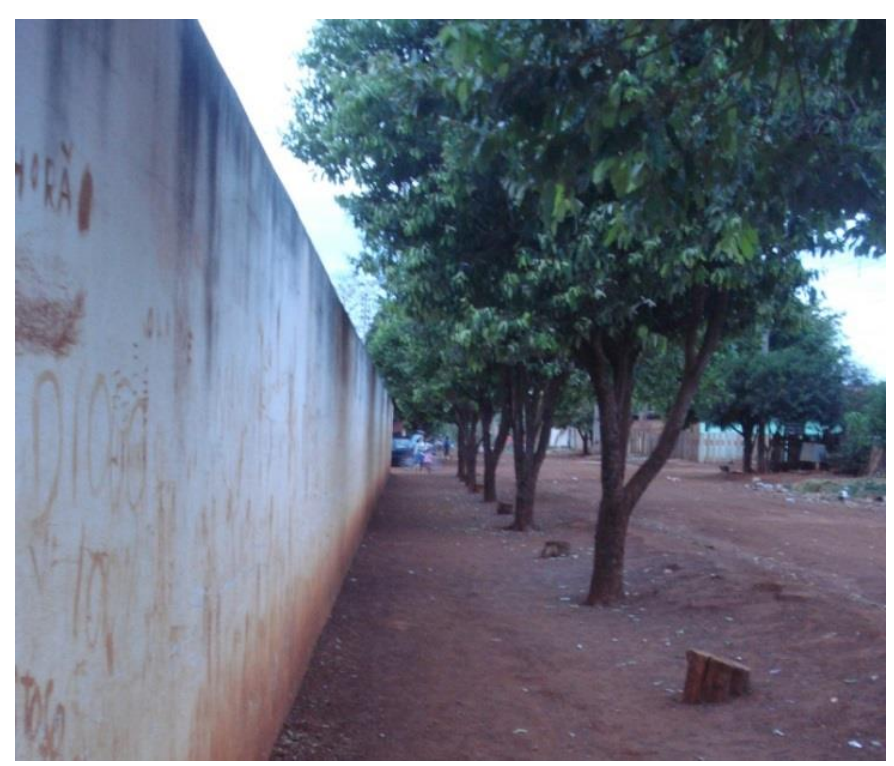

Figura10: Entorno do CME Gentila Susin Muraro

Fonte: Acervo pessoal dos autores, 2013.

A entrada principal da escola possui um percurso curto ao ar livre. A entrada secundaria é direcionada ao refeitório onde se concentra boa parte do uso da área externa da escola.

O terreno da escola é caracterizado por um declive natural do terreno em conjunto com as condições de uma topografia acidentada em função da erosão causada pelo escoamento das águas sem um tratamento adequado. O terreno possui uma extensa área onde a ocupação por parte das edificações ocorre de modo próximo e concentrado.

De modo geral a acessibilidade da área externa da escola (figura 11) é precária, contando com vários obstáculos criados por calçadas, rampas e fossas.

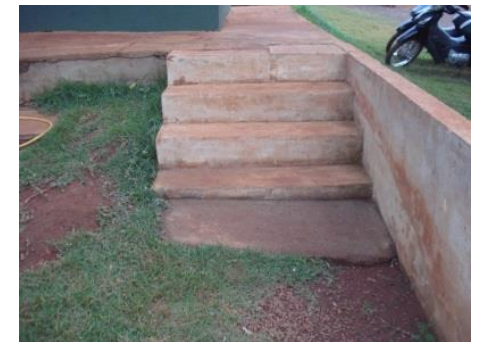

$\mathbf{a}$

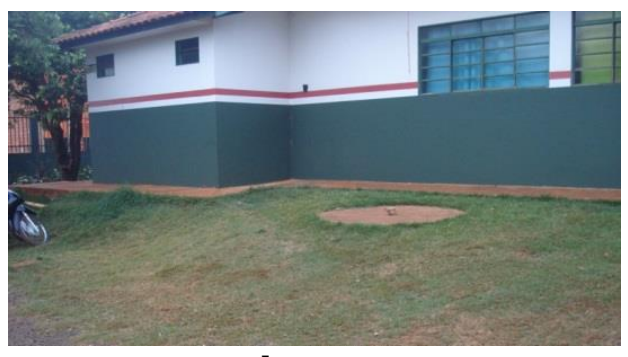

b

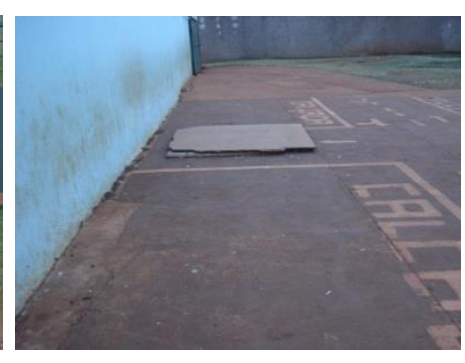

c

FigurA 112: (A) ESCADA ACESSO ESTACIONAMENTO (B) FOSSA (C) CAIXA DE GORDURA

Fonte: Acervo pessoal dos autores, 2013.

Quanto ao paisagismo da escola percebe-se uma iniciativa na entrada principal (figura 12) com o uso de flores, grama, arvore e um banco. Nos demais espaços têm- se o plantio desordenado a partir 
de uma monotonia vegetal (mesmas espécies arbóreas), em alguns pontos encontra-se presente a tentativa de um gramado. Relatos da diretora da escola mostram a tentativa de plantio de arvores em alguns pontos, mas todos sem êxito.
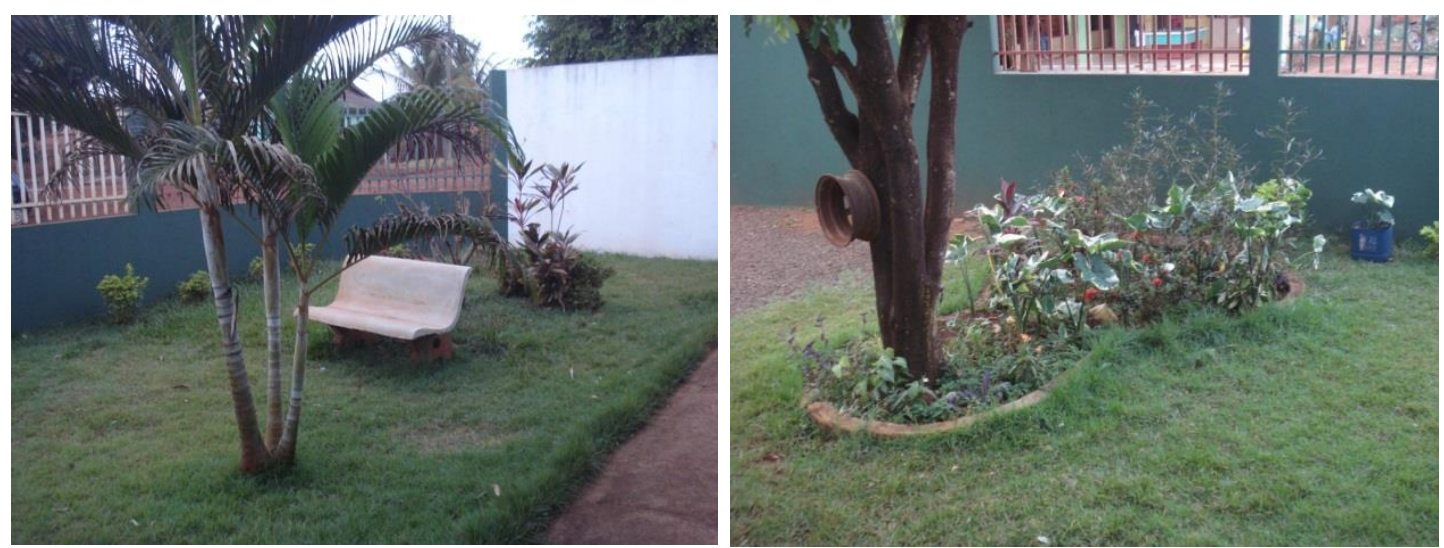

Figura 12: Iniciativa de Paisagismo

Fonte: Acervo pessoal dos autores, 2013.

Foi possível observar que o bloco das salas de aula cria um espaço de transição de ambientes da área externa da escola. A parte do terreno onde se concentram os blocos de salas de aula e refeitório posiciona-se em uma parte plana do terreno; o recobrimento do piso nesta área externa é solucionado por um extenso piso pavimentado em cimento com pequenos espaços com plantio de grama (figura 13); percebe-se pintado no piso a demonstração de faixas de pedestres para educação sobre o transito além de amarelinha.

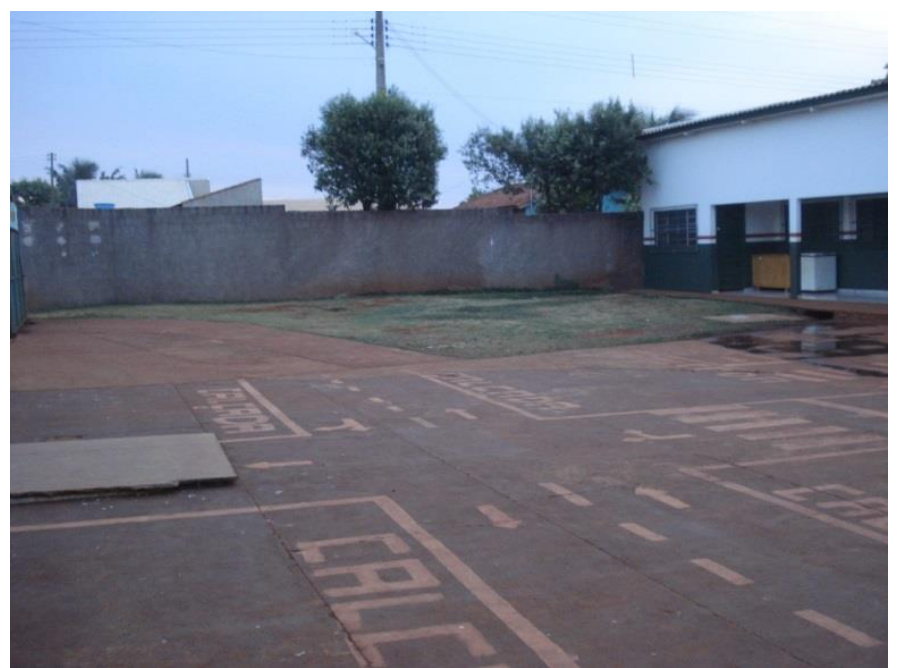

Figura 13: Demonstração de faiXas de Pedestres no PÁtio

Fonte: Acervo pessoal dos autores, 2013.

Já a parte posterior às salas de aulas é dotada de um amplo espaço cujo uso é restrito a alguns pontos pela falta de estrutura, onde apresenta um ambiente árido, pouco sombreado, escassez de 
vegetação, ausência de locais para o convívio e atividades com os alunos, pavimentação apenas para as estreitas calçadas de modo que o que predomina é o chão batido. Nesta parte da área externa da escola (figura 14) localiza-se a quadra poliesportiva, o campo de futebol, a quadra de areia, o parquinho, a horta e o estacionamento dos professores.
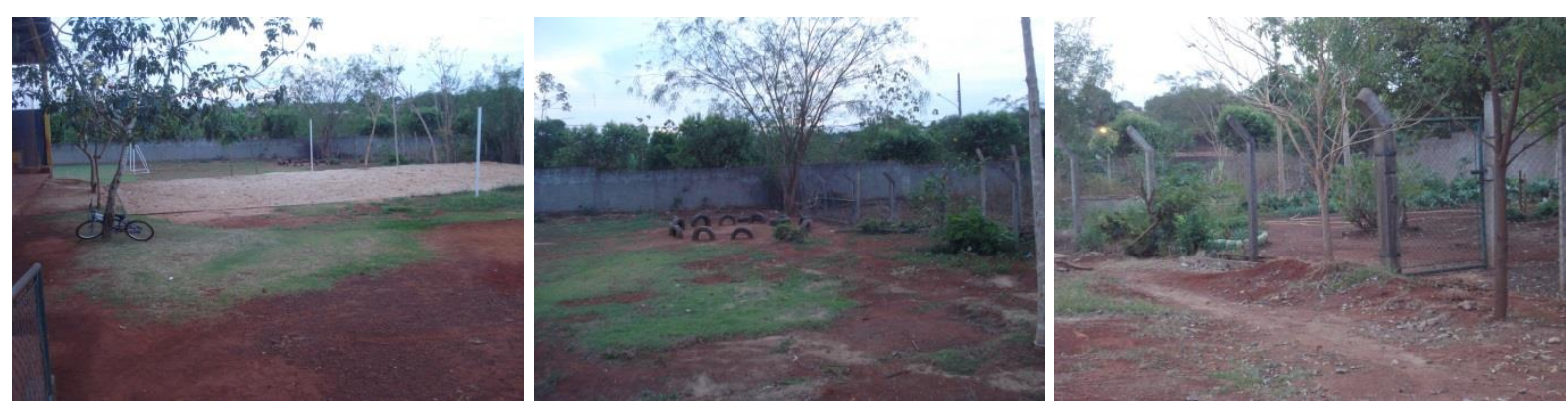

FIgURA 14: AUSÊNCIA DE LOCAIS PARA O CONVÍVIO E ATIVIDADES COM OS ALUNOS

Fonte: Acervo pessoal dos autores, 2013.

A quadra poliesportiva, que é além do refeitório da escola o espaço que possibilita o uso em comum dos alunos em um ambiente coberto, deste modo, são realizadas várias atividades ao mesmo tempo, como por exemplo, aulas de karatê e fanfarra disponibilizados pelo Projeto Mais Educação em conjunto com as aulas de educação física.

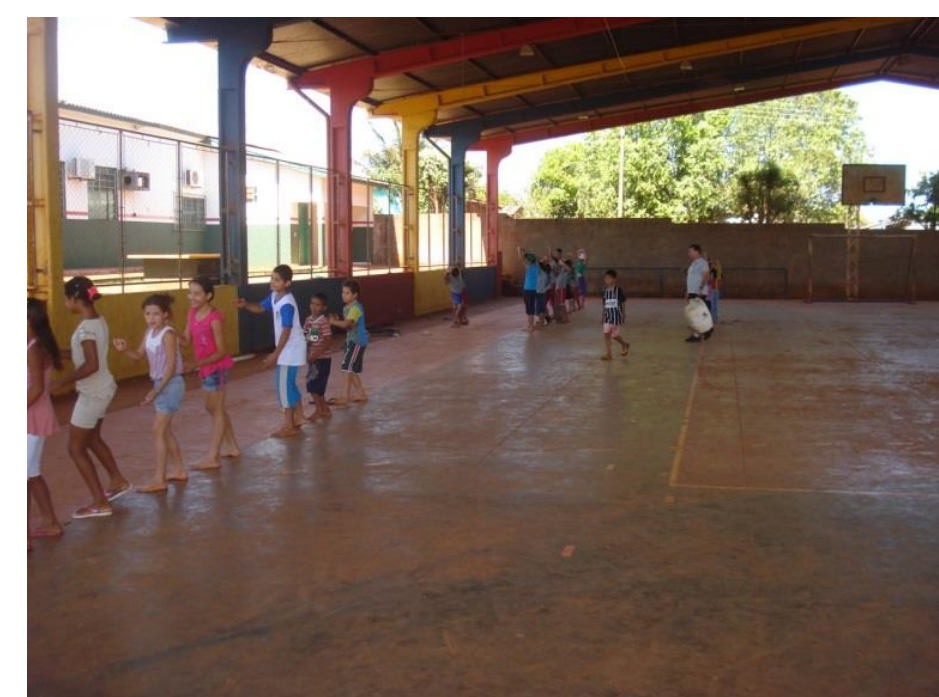

Figura 15: VÁRIAS ATIVIDADES AO MESMO TEMPO - QUADRA POLIESPORTIVA

Fonte: Acervo pessoal dos autores, 2013.

O campo de futebol, feito com a iniciativa de alguns professores, é utilizado para a prática do esporte como também para a realização de brincadeiras como rouba-bandeira, queimada, pega-pega.

A quadra de areia (figura 16) apresenta-se como um espaço sem manutenção e infraestrutura, onde seu posicionamento em pleno sol é limita seu uso. 


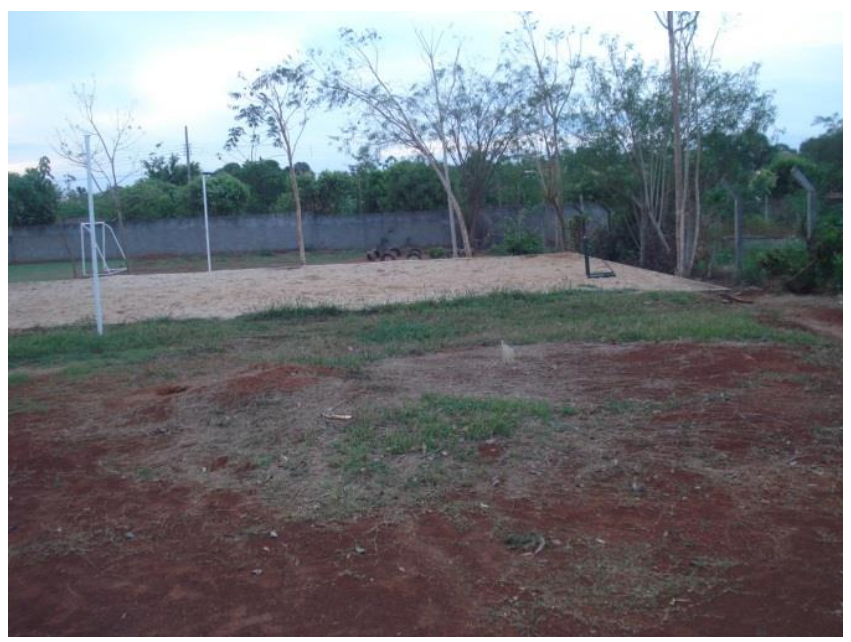

FigurA 16: QUADRA DE AREIA

Fonte: Acervo pessoal dos autores, 2013.

A horta da escola possui uma variedade de hortaliças cuidadas por um zelador da escola, contudo o espaço não apresenta uma infraestrutura como canteiros, espaço para irrigação e estufa, por exemplo, o que dificulta o cultivo adequado e permite que ervas daninhas estejam presentes como foi percebido. A horta ainda possui um amplo espaço de um antigo mandiocal (figura 17), hoje sem uso e manutenção.

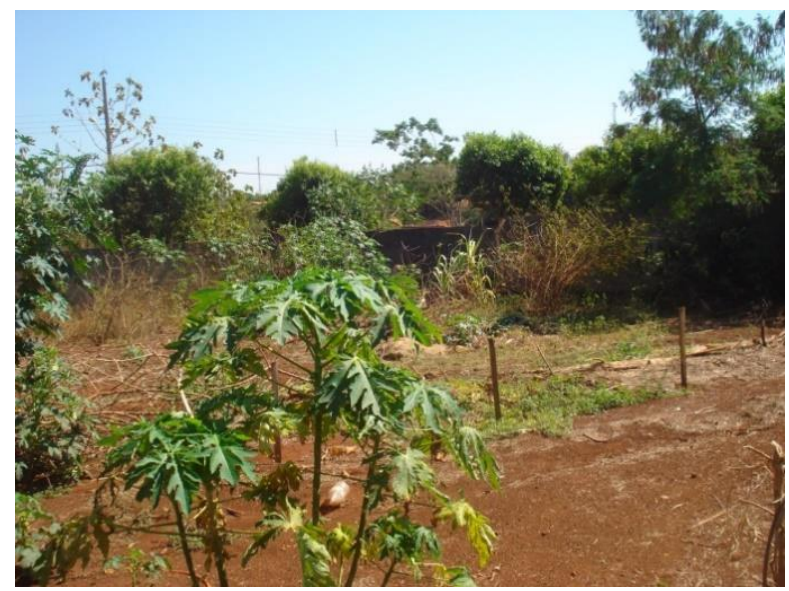

FIGURA 173: HORTA

Fonte: Acervo pessoal dos autores, 2013.

O parquinho é destinado apenas aos menores, localizado em um espaço de acesso restrito por alambrado e portão, possui areia como pavimentação. Os brinquedos estão em estado de uso e em seu interior conta com algumas arvores. De acordo com a Diretora Miriam pretende-se destinar este espaço as instalações do Projeto Mais Educação contando com uma área coberta para a realização das atividades desenvolvidas pelos alunos. 
Ao lado do parquinho está o estacionamento de carros e motos dos funcionários da escola (figura 18), apresenta-se de modo desordenado devido à falta de espaço para o direcionamento das vagas.

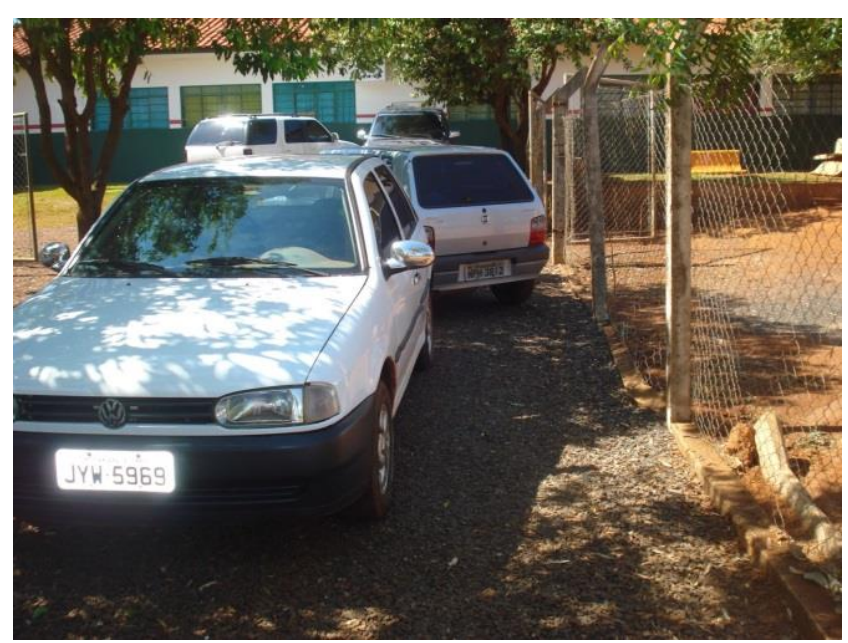

FigURA 18: ESTACIONAMENTO INTERNO

Fonte: Acervo pessoal dos autores, 2013.

De modo geral a escola não apresenta o uso de cores, a não ser as que representam o município, utilizadas como característica padrão das pinturas da envoltória das edificações municipais.

\section{Mapa Comportamental}

A observação foi elaborada em um único dia (06 de setembro de 2013) das 09:00 horas até as 16:00 horas acompanhando deste modo a rotina de uso da área externa da escola nos períodos matutino e vespertino.

O principal objetivo era entender como o espaço físico é apropriado pelos usuários e ao mesmo tem sua influência em suas relações, ou seja, se condições de circulação e deslocamento e questões ambientais, entre outras, favorecem a qualidade espacial e social aos usuários.

Buscou-se visualizar como os aspectos físicos do pátio interferem no comportamento dos usuários, observando os seguintes aspectos:

- $\quad$ territorialidade, limites e privacidade;

- $\quad$ interação dos usuários (criança-criança e criança-adulto);

- deslocamentos no espaço, restrições espaciais ou obstáculos;

- $\quad$ autonomia e acesso ao mobiliário, brinquedos e equipamentos;

- $\quad$ condições ambientais; 
- $\quad$ locais preferidos;

- $\quad$ interação interior/exterior.

Para a análise das observações realizadas, dividiu-se a área externa da escola em duas partes, sendo elas o pátio do refeitório e pátio das atividades esportivas.

Os alunos em sua maioria se concentram no pátio próximo ao refeitório, sendo este espaço de maior uso quando se trata de áreas externas. É neste espaço que os alunos se concentram na chegada para a aula, de modo que os menores esperam em fila por seus professores e os demais se dirigem a porta de suas salas a espera do sinal.

No intervalo os alunos se concentram apenas neste local, por determinação da direção da escola para melhor controle dos alunos. Durante o intervalo que ocorre por idades, a Diretora e a Coordenadora estão presentes a fim de garantir a ordem dos alunos quanto a correria.

Durante o recreio, as refeições ocorrem dentro do refeitório que possui mesas e bancos para as refeições, os demais, se espalham por este pátio sempre em grupos, alguns se concentram próximo ao muro disputando o pouco de sombra existente, outros brincam de pega-pega, amarelinha, cantigas, ouvem musicas, ficam nos corredores das salas de aula em busca de sombra.

Pela falta de locais para sentar, foi possível notar que o bebedouro, construído com alvenaria convencional, é utilizado para este fim.

Neste pátio a insolação está presente em todos os horários de intervalo, ocorrendo a sombra a partir das 16:00 horas.

Foi possível observar ainda que vários desníveis e buracos que podem causar acidentes convivem com a brincadeira dos alunos sem qualquer medo.

O pátio das atividades esportivas tem seu uso a partir das 08:30 horas no período matutino e às 13:00 horas no período vespertino, sendo um espaço amplo e sem estrutura, os alunos se concentram apenas em pontos focais. Os alunos que utilizam este espaço são apenas aqueles que estão participando do Projeto Mais Educação e aqueles que estão nas aulas de Educação Física. Como ponto de concentração dos alunos a quadra poliesportiva condiciona os alunos em várias atividades simultaneamente.

O parquinho é utilizado apenas com o acompanhamento dos professores. O campo de futebol e quadra de areia tem seu uso mais frequente a partir das 16:00 horas onde o sol já não é incidente.

\section{Análise do Nível de Satisfação dos Usuários}




\section{Seleção Visual}

O método Seleção Visual foi aplicado nos dias 23 e 24 de setembro durante os turnos matutino e vespertino com 74 alunos do $4^{\circ}$ ao $9^{\circ}$ com idades de 11 a 17 anos.

Para o direcionamento sobre as opiniões dos alunos, espaços focais determinados após observação do uso e potencialidade dos mesmos, foram apresentados aos alunos através do formulário onde deveriam apresentar os pontos positivos e negativos daquele espaço, a fim de compreender porque e quando o frequentam, se gostam ou não de estar em determinado espaço e o que é bom ou ruim.

TABELA 5: SELEÇÃo VisUAL

\begin{tabular}{|c|c|}
\hline $\begin{array}{l}\text { Figura 19: SeleÇão Visual - LoCAL de Convívio } \\
\text { Fonte: Acervo pessoal dos autores, } 2013 .\end{array}$ & $\begin{array}{l}\text { O espaço localizado próximo as salas de } \\
\text { aula (figura 82), com bancos e uma árvore } \\
\text { recebeu dentre seus aspectos positvos a } \\
\text { possibilidade de um local para sentar, } \\
\text { descansar e conversar com os amigos. } \\
\text { Sendo considerado um espaço de lazer, } \\
\text { alunos relataram que a sombra, pouco } \\
\text { presente na escola, é um beneficio que o } \\
\text { espaço oferece. } \\
\text { Dentre os aspectos negativos os alunos } \\
\text { relataram o vandalismo com os bancos } \\
\text { quebrados; a falta de estrutura presente no } \\
\text { chão de terra batida, pouca sombra, o } \\
\text { ambiente mórbido sem cores e flores , } \\
\text { foram apontados como signnificativos para } \\
\text { não estarem mais tempo neste local. }\end{array}$ \\
\hline 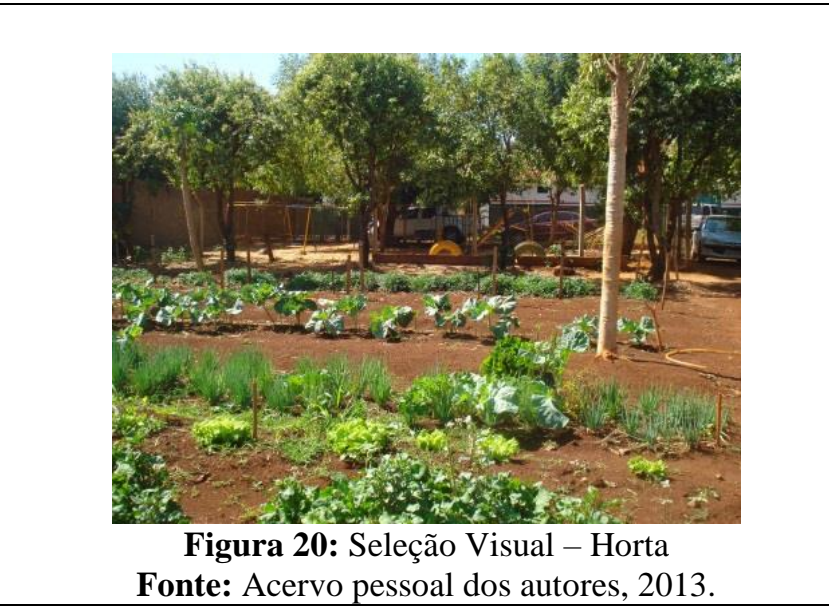 & $\begin{array}{l}\text { A horta (figura 83) da escola é apresentada } \\
\text { em seu cotexto de pontos positivos como } \\
\text { um benefico a todos por ser fonte de parte } \\
\text { do cardapio da escola contendo uma } \\
\text { variedade de verduras. } \\
\text { Nos pontos negativos a falta de estrutura é } \\
\text { apresentada como fator geral que acarreta } \\
\text { circunstâncias como o acumulo de mato e } \\
\text { lixo. Alguns alunos apresentaram como } \\
\text { negativo o fata de não poderem aprender a } \\
\text { cultivar verduras bem como a falta de um } \\
\text { pomar junto a horta. }\end{array}$ \\
\hline & $\begin{array}{l}\text { A quadra de areia (figura 84) foi } \\
\text { apresentada em seus pontos positivos } \\
\text { como local de lazer, onde se é gostoso de } \\
\text { brincar principalmente jogando volei. } \\
\text { No que tange os pontos negativos fatores } \\
\text { como a areia suja, pedras ao redor da }\end{array}$ \\
\hline
\end{tabular}




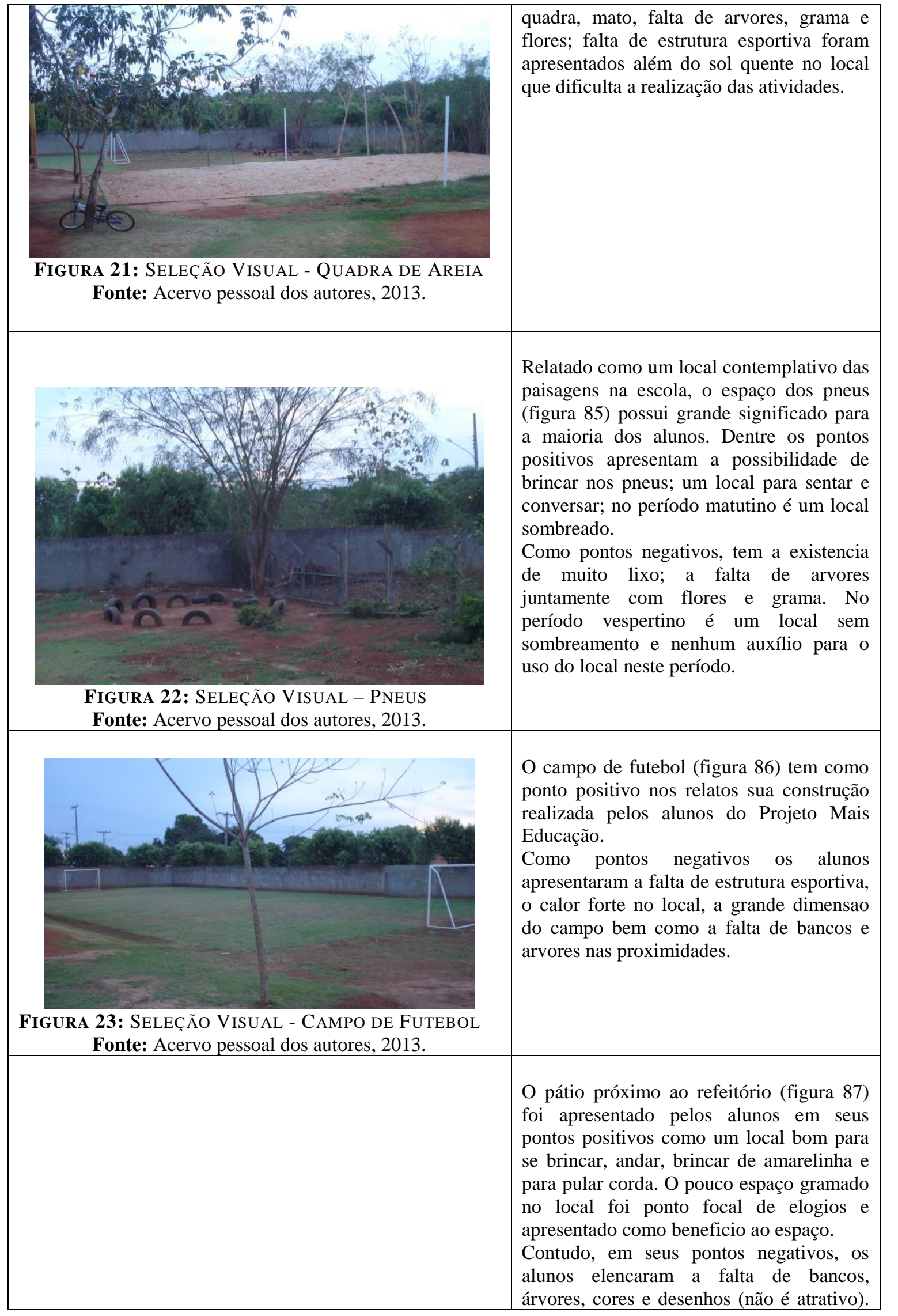




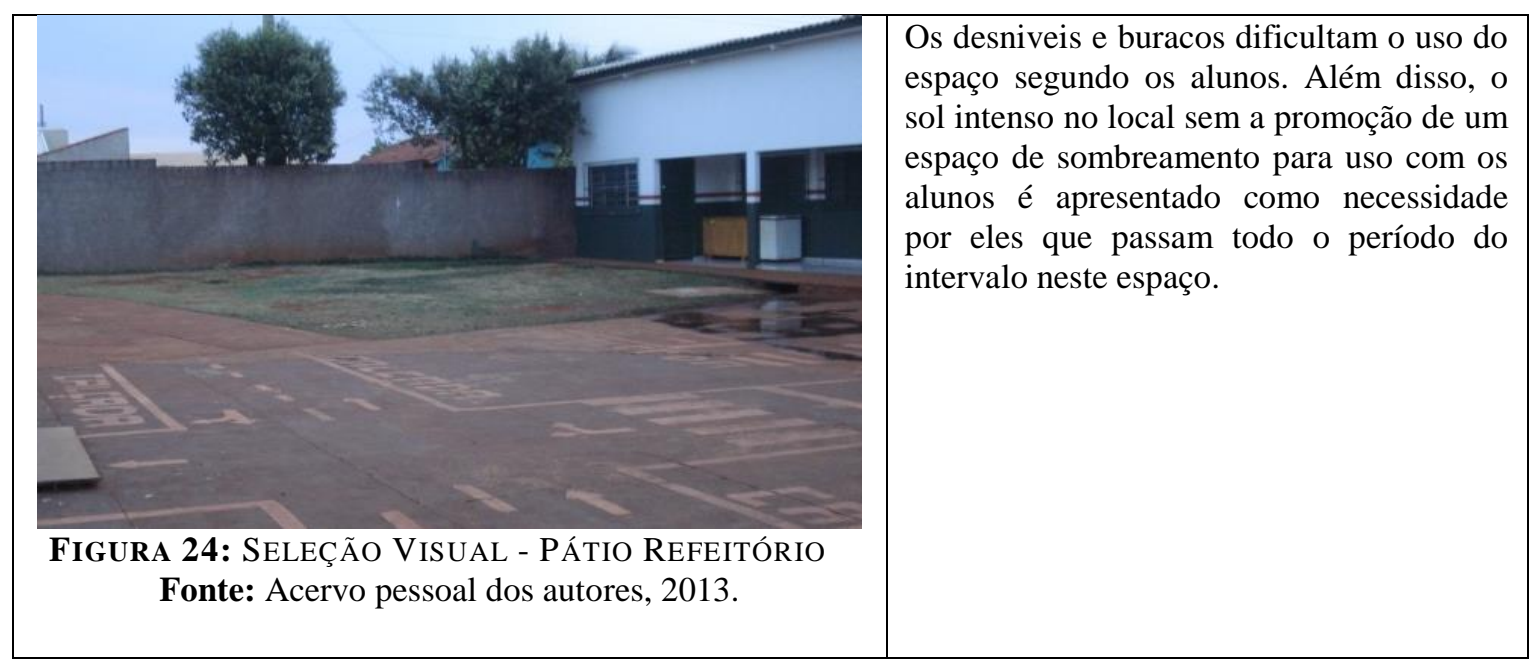

Fonte: Elaborado pelos autores, 2013.

\section{Poema de Desejos}

A aplicação do instrumento ocorreu no dia 27 de setembro nos períodos matutino e vespertino, com alunos do Pré I ao $3^{\circ}$ ano do Ensino Fundamental totalizando 78 alunos com idades de 04 a 10 anos. As atividades ocorreram na biblioteca da escola espaço cedido pela Diretora, onde apenas os alunos que participavam do método utilizavam o espaço.

Realizado com uma amostra de cada turma por vez, foi oferecido o formulário e lápis de cor em companhia dos pesquisadores. $\mathrm{O}$ intuito do método era explicado aos voluntários, que realizavam as atividades no tempo de 40 minutos em média.

Dentre os resultados obtidos pode-se observar um grupo de alunos que relacionavam seus desenhos a um objeto especifico como, por exemplo, bola, coração, árvores, sol chuva, animais, membros de sua família, dentre outros, sem um contexto geral sobre o que desejam expressar. É notório que a maioria destes desenhos foram representados objetos que aprenderam ou estão aprendendo a desenhar. Alguns dos desenhos serão apresentados a seguir: 


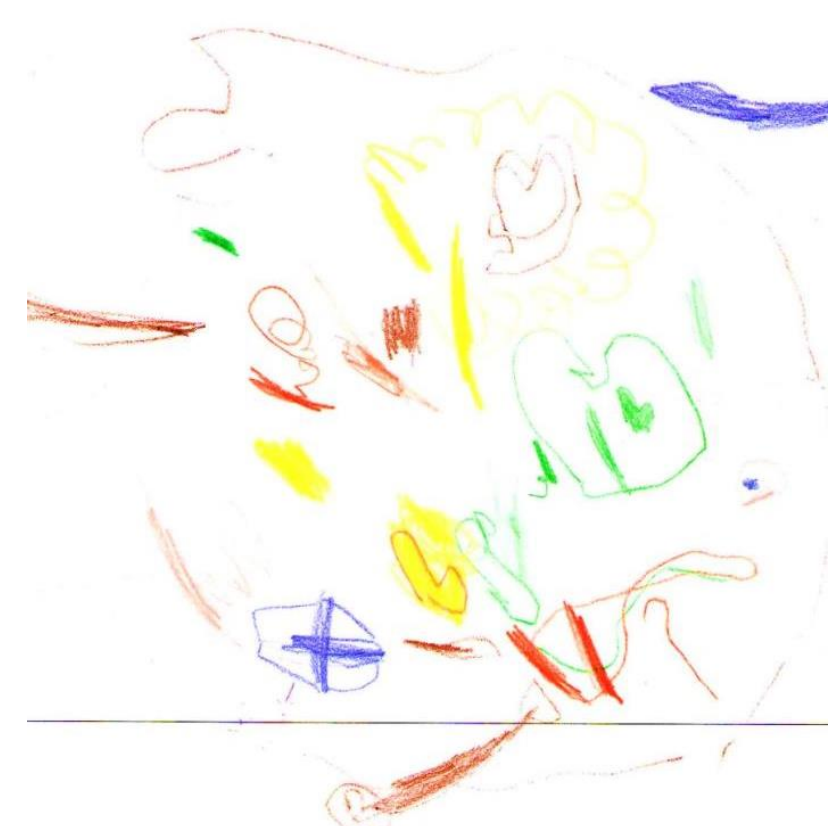

Figura 25: GABRIEL (05 ANOS) ALUNO do PRÉ I EM SEU DESENHO REPRESENTOU VÁRIOS ELEMENTOS COMO PIPA, CORAÇÃO, NUVEM E COBRA.

Fonte: Acervo pessoal dos autores, 2013.

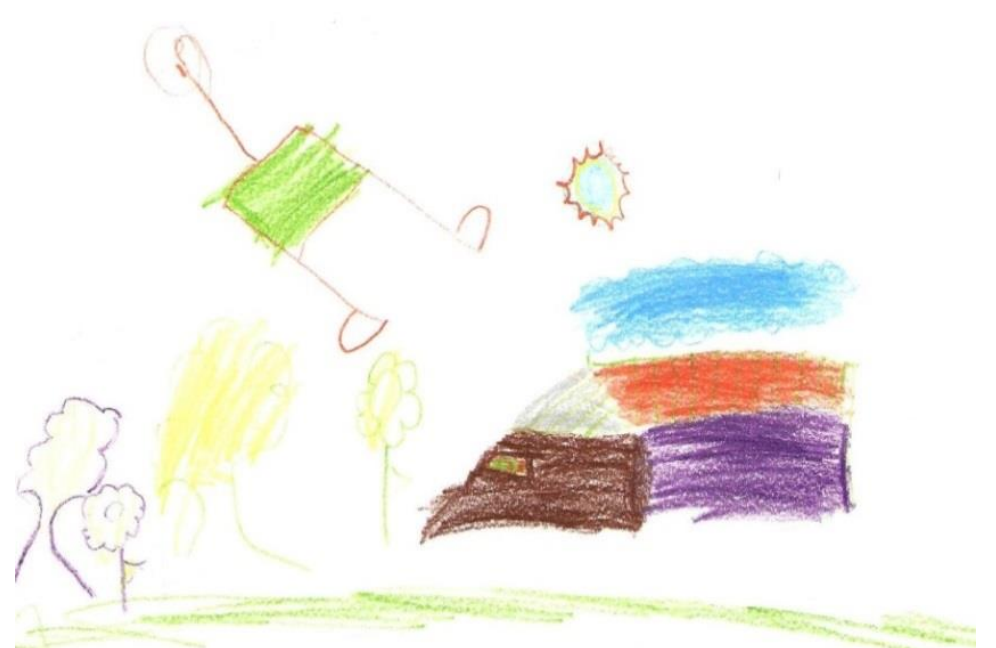

Figura 26: KAUÃ (05 ANOS) ALUNO do PrÉ II RELACIONOU EM SEU DESENHO UMA PAISAGEM COMPOSTA POR SUA CAS A, ÁRVORES E UM HOMEM NÃO ESPECIFICADO POR ELE.

Fonte: Acervo pessoal dos autores, 2013.

Outro grupo de alunos representou elementos da natureza, árvores, flores, céu e sol, grama, arco-íris, borboletas dentre outros exemplos, onde se observa que a concepção de pátio escolar em sua totalidade ainda não foi formada. 


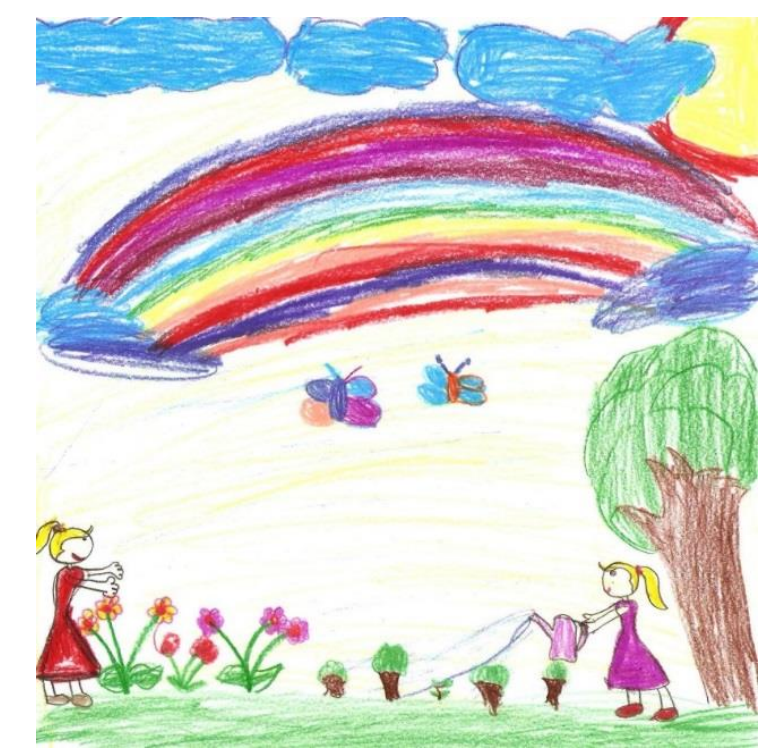

FIGURA 27: GEZIANE (08 ANOS) ALUNA do 2 ANO REPRESENTOU EM SEU DESENHO A MÃE EM SUA COMPANHIA EM CUIDANDO DE UM JARDIM FLORIDO.

Fonte: Acervo pessoal dos autores, 2013.

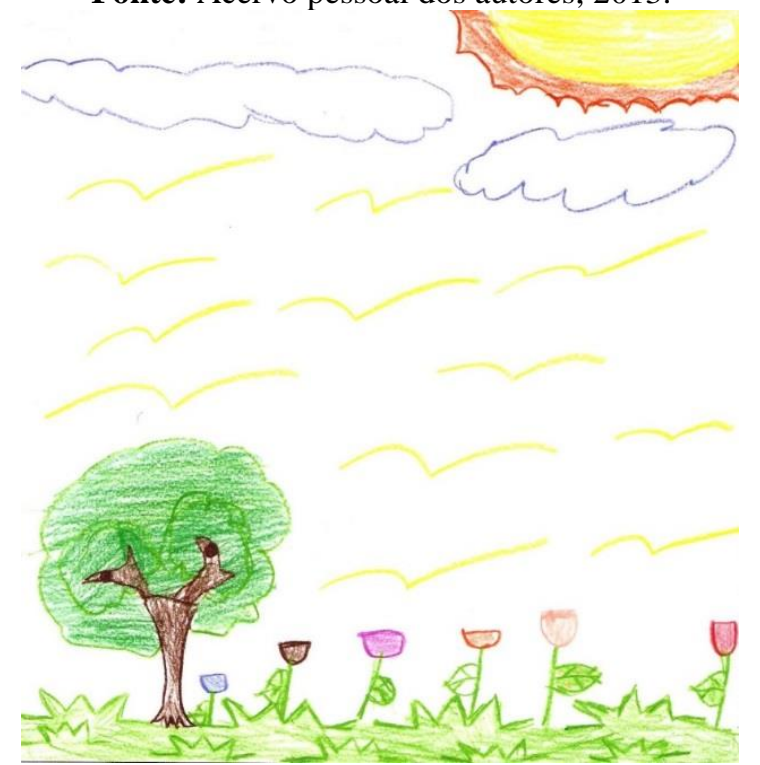

FigURA 28: ÉRICA (08 ANOS) ALUNA 3 ANO, EM SEU DESENHO REPRESENTOU APENAS ASPECTOS DA NATUREZA, QUE EM SUA OPINIÃO DEVERIAM ESTAR PRESENTES NO PÁTIO DE SUA ESCOLA FLORES, GRAMA E ÁRVORE.

Fonte: Acervo pessoal dos autores, 2013.

O último grupo de alunos representou o pátio escolar onde apresentam elementos da natureza, o pátio existente na escola, mobiliários como bancos e o parquinho, e acima de tudo, incluem nos desenhos a professora, colegas de turma e eles próprios. 


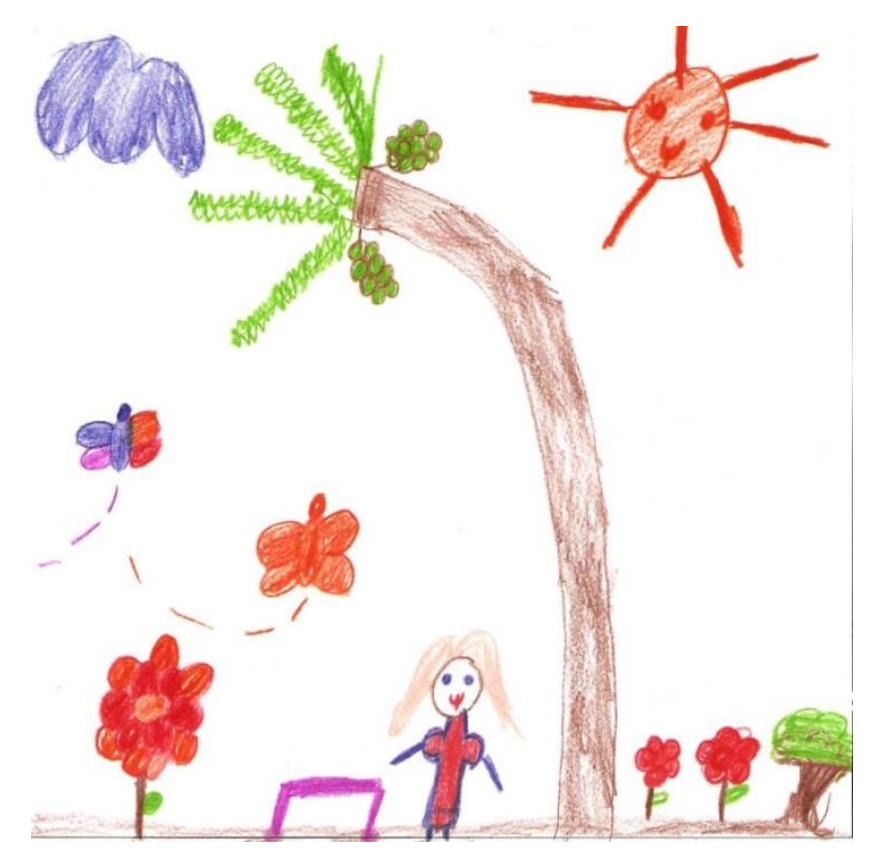

Figura 29: TAinÁ SANTOS (07 ANOS) ALUNA do $1^{\circ}$ ANO SE REPRESENTOU NO PÁtio de SUA ESCOLA EM UM DIA ENSOLARADO COM ÁRVORES, FLORES, BORBOLETAS E UM BANCO POSICIONADO SOB A SOBRA DO COQUEIRO.

Fonte: Acervo pessoal dos autores, 2013.

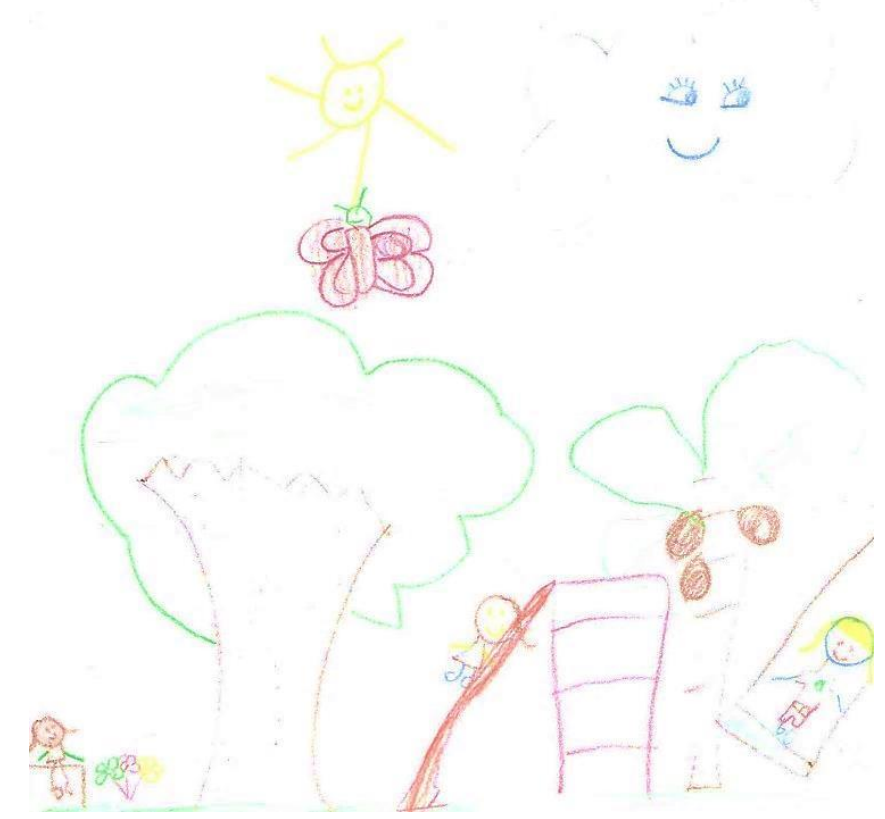

Figura 29: TAINÁ (06 ANOS) ALUNA do 1ªno, APRESENTOU EM SEU PÁTIO ESCOLAR O CONVÍviO COM AMIGAS EM UM PARQUINHO COM ESCORREGADOR, BALANÇO E BANCO. COMPONENTES DA NATUREZA COMO ÁRVORES, FLORES, BORBOLETA PRESENTES EM UM DIA ENSOLARADO.

Fonte: Acervo pessoal dos autores, 2013. 


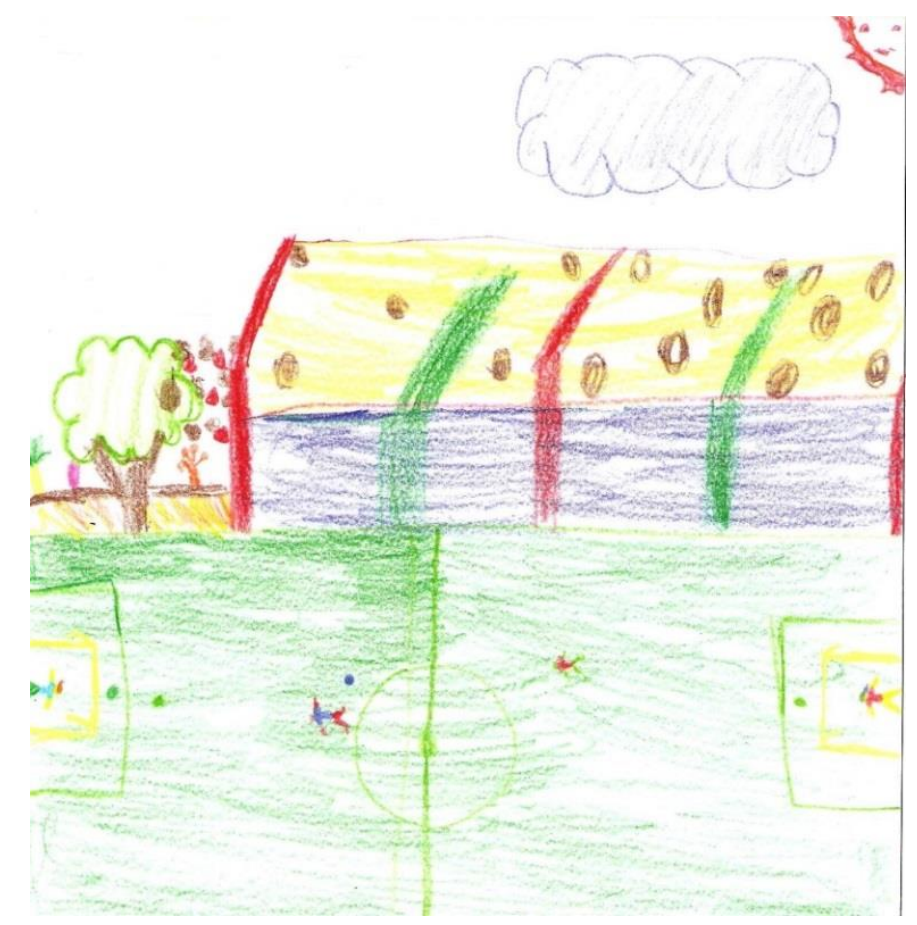

Figura 29: Wellington (09 ANOS) ALUNO DO 3 ANO APRESENTOU A QUADRA POLIESPORTIVA DA ESCOLA JUNTAMENTE COM O CAMPO DE FUTEBOL. O ALUNO AINDA INCORPOROU A NECESSIDADE DE UMA ÁREA SOMBREADA NAS PROXIMIDADES DA QUADRA.

Fonte: Acervo pessoal dos autores, 2013.
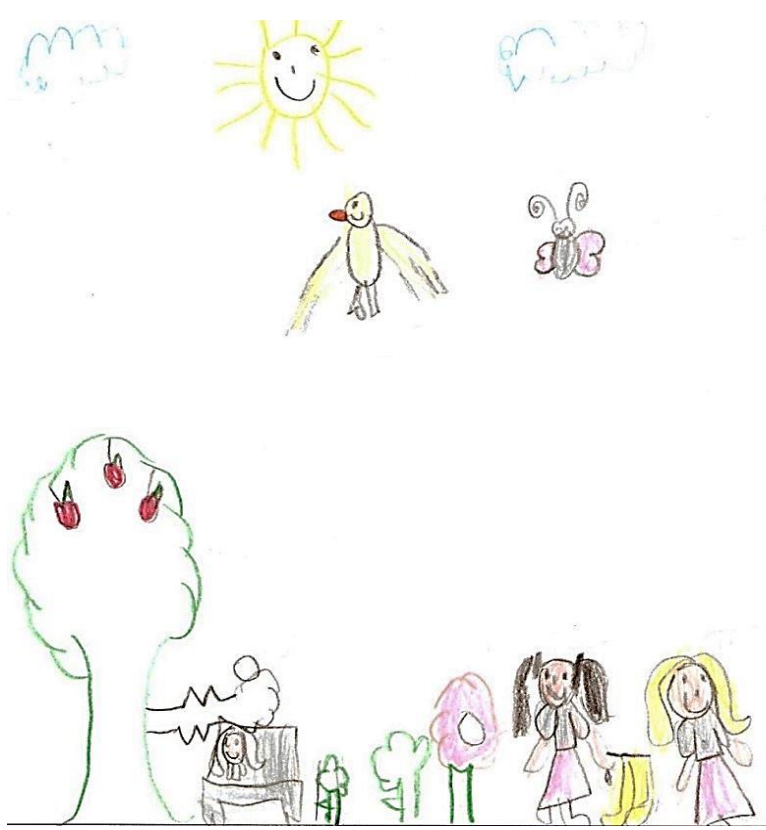

Figura 30: Elois a (06 ANOS) ALUNA DO $1^{\circ}$ ANO DESENHOU O CONVÍVIO NO PÁTIO COM OS COLEGAS DE CLASSE, EM UM ESPAÇO COM A PRESENÇA DE ELEMENTOS NATURAIS. EM SUA EXPLICAÇÃo SOBRE O DESENHO, DEU DESTAQUE AO BANCO QUE ESTÁ NA SOMBRA, O QUE NÃO OCORRE EM SUA ESCOLA.

Fonte: Acervo pessoal dos autores, 2013. 
Os desenhos apresentam o anseio de poder conviver na área externa da escola de maneira agradável, boa parte dos desenhos é possível observar o uso de várias cores na busca de um lugar com aspectos alegres. Além disso, as representações mostram locais de uso comum sem individualidades.

\section{Mapeamento Visual}

O método foi aplicado com 74 alunos do $4^{\circ}$ ao $9^{\circ}$ ano dos períodos matutino e vespertino durante os dias 20, 23 e 24 de setembro. Desenvolvido em sala de aula, os alunos receberam o formulário (apêndice D) onde a área externa da escola (figura 103) foi setorizada em quatro pátios para o questionamento de onde mais gostam de estar e onde menos gostam.

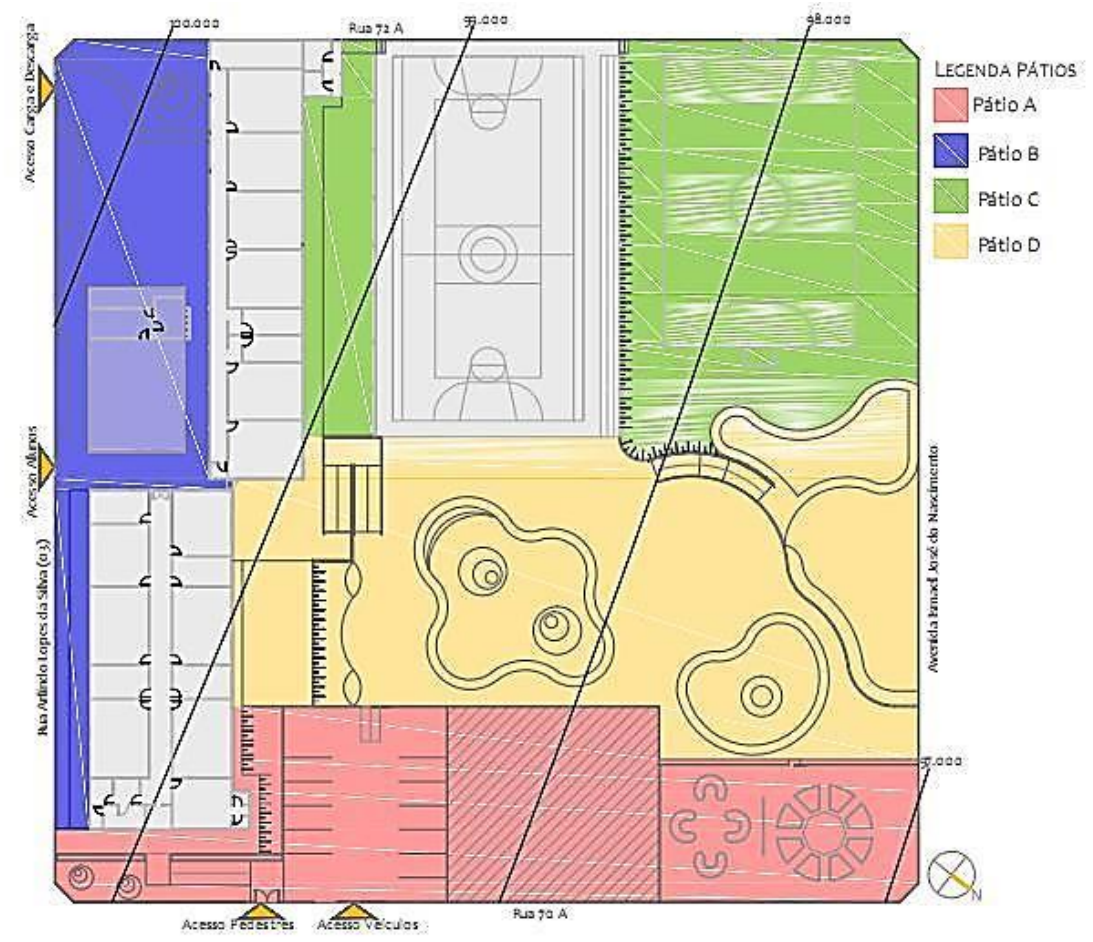

Figura 31: SetorizaÇão Mapeamento Visual

Fonte: Elaborado pela autora, 2013.

O Pátio A localizado próximo à entrada principal e bicicletário foi apontado pela maioria dos alunos como local onde menos gostam de estar. Isso se deve a fatores como a restrição ao acesso a esse local, além disso, o espaço não possui aspectos atrativos e convidativos como, por exemplo, bancos para o convívio. 
Apresentado em sua maioria como um local onde mais gostam de estar, o Pátio B é um dos espaços externos onde os alunos tem maior período de permanência. Sendo considerado como o único lugar onde podem relaxar, conversar com os amigos, sentar em grupo, ouvir musica, a área coberta do refeitório é o único espaço sombreado. Dentre os pontos que desfavorecem o Pátio B os alunos citam a falta de bancos e sombras e a correria durante o intervalo ocasionada pela falta de atividades neste ambiente.

Dos 75 alunos pesquisados, 49 indicam o Pátio C como local onde mais gostam de estar. Essa preferencia se deve a fatores como a estrutura existente que permite o uso confortável dos alunos, por ser um espaço destinado ao esporte e atividades de lazer e brincadeiras.

Sendo o Pátio D com maior espaço é apresentado pelos alunos como um local em potencial para o uso de diversas atividades, mas indicado com ressalvas como, por exemplo, deveriam ter mais árvores para maior conforto na hora do recreio; não tem atrativos; sol muito quente; necessidade de um jardim com mesas, bancos, gramado flores, ambiente que proporcione o convívio entre os alunos. O parquinho, a horta e os pneus existentes neste pátio foram relatados como referencia de locais onde os alunos gostam de estar.

\section{Questionário}

O questionário foi aplicado com os alunos de $4^{\circ}$ ao $9^{\circ}$ ano (74 voluntários) com formato de perguntas fechadas sobre a área externa da escola.

A primeira pergunta destinava-se ao conhecimento sobre a satisfação dos alunos quanto à área externa, a fim de saber se ela é atrativa, obteve-se como maior parte das respostas positivas. Vale ressaltar que no decorrer da aplicação do questionário alguns alunos pediram explicação sobre o que é atrativo.

\section{Você acha a área externa da sua escola atrativa?}

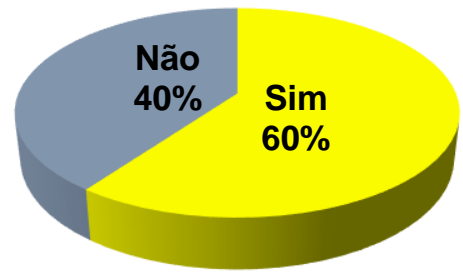

\section{GRÁFICO 01}

Fonte: Elaborado pelos autores, 2013. 
A segunda pergunta, sobre os locais da área externa onde mais gostam de estar, a quadra poliesportiva é apresentada como local de preferencia da maioria, seguida pela quadra de areia. Os demais locais apresentados possuem preferencias próximas. A quadra poliesportiva é ponto de referência assim como já foi notado em outros instrumentos aplicados, afinal este é um dos poucos ambientes que promovem conforto em seu uso, se tratando da área externa.

\title{
2. Na área externa em que locais você mais gosta de estar?
}

- quadra de areia
- campo gramado
- horta

\author{
a quadra poliesportiva (coberta) \\ - o pátio próximo ao refeitório
}

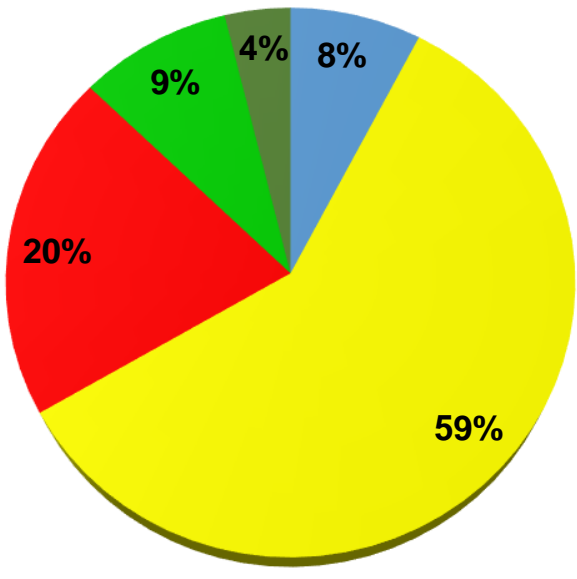

\section{GRÁfICO 02}

Fonte: Elaborado pelos autores, 2013.

A terceira pergunta, destinava-se ao conhecimento dos anseios no uso do pátio da escola a partir do que os alunos gostariam de fazer. Tem-se destaque a vontade de se ter na escola um local sombreado para descansar com os colegas, algo longe da realidade enfrentada pelos alunos. Em seguida, jogar com os colegas xadrez, dama, ludo e cuidar de um jardim florido, mostram que é preciso haver uma distribuição do uso do pátio, a fim de promover atividades em grupo ocasionando assim, o ordenamento dos alunos em seu período de uso. O questionamento se inicia com a afirmação de que no pátio ocorre a brincadeira, pois em diversos momentos de observação do uso da escola é notório que boa parte dos alunos utilizam o pátio para este fim. 


\title{
3. No pátio da escola, além de brincar você gostaria de:
}

\author{
- estudar (atividades fora da sala de aula) \\ - cuidar da horta \\ - cuidar de um jardim florido \\ - jogar com os colegas (xadrez, dama, ludo e outros) \\ um local sombreado para descansar ao lado dos colegas \\ - ser responsável pela construção e cuidado de algum local
}

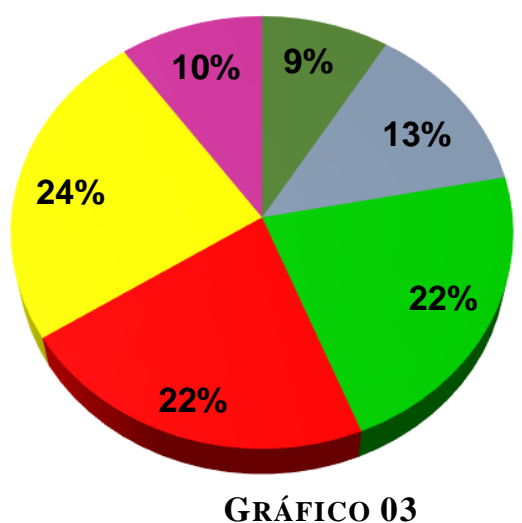

Fonte: Elaborado pelos autores, 2013.

A quarta pergunta é destinada a criação de novos ambientes no pátio da escola, para tanto, as perguntas estavam voltadas a proposta de ambientes de uso comum. Um local para brincadeiras foi apresentado como maior anseio dos alunos um local para brincadeiras, seguido de área para descanso e por fim, local para atividades em grupo.

\section{No pátio da escola você gostaria que tivesse:}

um local para atividades em grupo a área para descanso local para brincadeiras

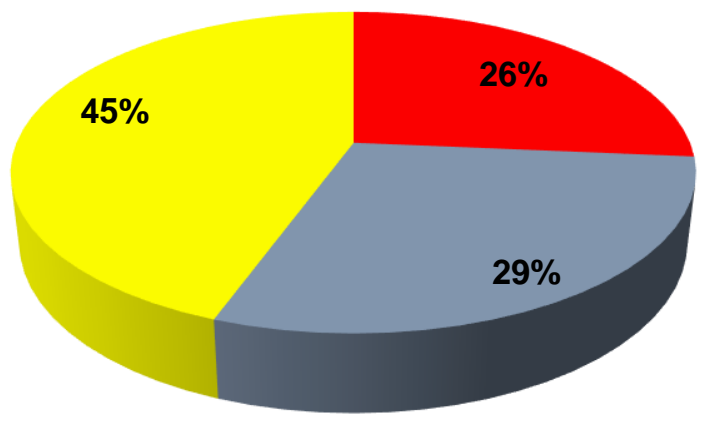

\section{GRÁFICO 04}

Fonte: Elaborado pelos autores, 2013. 
A quinta pergunta apresenta elementos que deveriam estar presentes na área externa da escola. $\mathrm{O}$ questionamento era direcionado ao que mais os alunos sentem falta na área externa da escola, de modo que área sombreada foi apontada pela maioria dos alunos, seguido de flores, árvores, bancos e mesas, cores e desenhos e por fim gramado. Com esta pergunta é notório que os alunos entendem que determinados elementos melhoram a qualidade do pátio escolar.

\section{Quanto às áreas externa da sua escola você sente falta de:} áreas sombreadas $₫$ árvores $₫$ gramados $₫$ flores $\backsim$ bancos e mesas $₫$ cores, desenhos

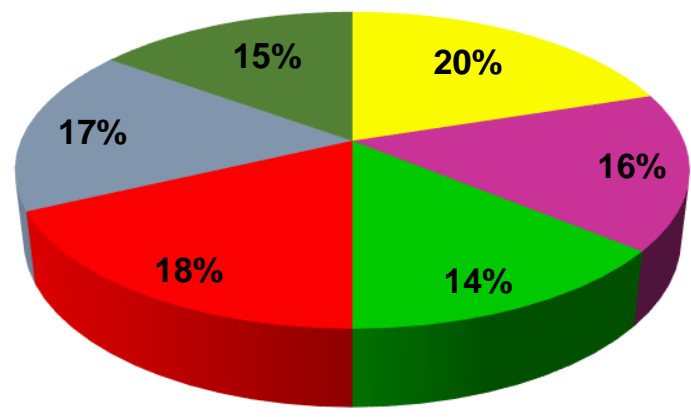

\section{GrÁFICO 05}

Fonte: Elaborado pelos autores, 2013.

A sexta pergunta, referente as atividades que gostariam que tivessem fora da sala aula de aula. Esta pergunta foi elaborada para a idealização de ambientes a serem criados no pátio da escola, na promoção de atividades extracurriculares. Atividade de esportes foi apontada pela maioria dos alunos como o grande anseio, seguido das atividades de artes: música, dança e teatro; a terceira opção mais votada são as atividades visuais: desenho, pintura e trabalhos manuais e por ultimo atividades de leitura fora da sala de aula. É notório que os alunos da escola desejam atividades práticas, que podem envolver diversas disciplinas em uma mesma atividade. 


\section{Quais atividades fora da sala de aula você gostaria \\ que tivesse em sua escola? \\ - atividades de leitura fora da sala de aula \\ atividades de esportes \\ - atividades envolvendo a horta da escola}

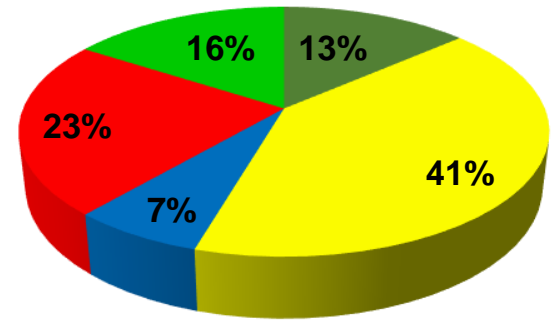

GrÁFICO 06

Fonte: Elaborado pelos autores, 2013.

\section{Cruzamento de Dados: Proposta de Diretrizes}

Antes de iniciar a análise, vale ressaltar que a interpretação dos dados não é única e fechada, ela é composta de emoções, sentimentos e percepções vivenciados na ocasião desta pesquisa. De acordo com Maturana (2001) a observação pressupõe a diversidade da experiência humana. Ele afirma que todos os aspectos da realidade podem ser levados em conta desde que sejam definidos com coerências operacionais explicativas do observador. Sendo assim, a análise destes dados não está fechada em si, muito menos tendo seu fim aqui. Os resultados apresentados e a interpretação realizada permitem a realização de conexões e correlações com o que aqui for apresentado.

O CME Gentila Susin Muraro é uma instituição de porte médio que nos dois turnos atende cerca de 610 alunos ofertando o ensino fundamental, sendo esta a etapa da vida escolar do aluno onde o pátio é cenário fundamental em seu processo de aprendizado.

O objeto de estudo é um claro exemplo de instituição escolar onde o pátio é o que sobra do terreno, de modo que seu processo de concepção projetual não levou em conta as possibilidades de integração com as áreas externas da escola, tendo em vista o amplo espaço ofertado à escola em seu terreno.

De modo que no decorrer da aplicação dos métodos esta desconexão do externo com o interno esteve presente em todos os momentos da pesquisa de campo. É notória a desconexão nos desenhos realizados pelos alunos no método poema de desejos, onde poucos apresentam o edifício escolar em 
seu pátio. Os acessos da escola não promovem o acolhimento e conforto dos alunos, pais e visitantes. Ao realizar as observações durante o mapeamento comportamental foi possível observar que os alunos se organizam para a espera do sinal em meio a obstáculos como, por exemplo, calçadas e rampas mal planejadas e a disputa por espaço com a mesa de concreto existente, sem um local adequado em que esta espera pudesse ocorrer. Não apenas espaços constituídos por paredes podem promover esta espera, mas o reordenamento do espaço com a criação de ambientes de convívio, com locais para sentar enquanto se espera, auxiliaria na rotina da escola.

Uma setorização previa do espaço externo da escola foi feita para a aplicação dos métodos que envolvem a opinião dos usuários. Esta setorização será aplicada também nesta apresentação dos resultados.

O pátio A que consiste ao local da entrada principal e do bicicletário é apresentado no método mapeamento visual como um local onde os alunos menos gostam de estar devido à falta de aspectos atrativos e convidativos, tendo presença momentânea neste ambiente. Durante o mapa comportamental a presença de alunos não foi notada. Neste pátio, há uma iniciativa de paisagismo por parte da escola, notada durante o Walkthrough, a única por sinal em toda a área externa da escola, desse modo, tem-se aqui um ponto de referência que deveria ser adotado em mais pontos da escola, o uso de flores, grama, mais árvores, propondo a diversidade de espécies a fim de promover com o paisagismo o reordenamento espacial, o conforto ambiental (térmico, visual, olfativo) do pátio da escola, fator de grande interesse dos alunos nos resultados do questionário.

O pátio B localizado próximo ao refeitório é o espaço de maior permanência dos alunos apresentado por eles como um local bom para se brincar, pular amarelinha, mas em seus relatos mostram que o espaço árido e com vários obstáculos impede que seu uso possa ser adequado. $\mathrm{O}$ pátio próximo ao refeitório é ponto de encontro dos alunos, é onde chegam e esperam até o momento da entrada para a sala de aula, é onde realizam suas refeições, sendo assim, espaços de convívio deveriam fazer parte deste cenário, com bancos e mesas. A aridez do ambiente que está sob o sol a pino poderia ser quebrada com a implantação de um paisagismo com arvores que garantisse o sombreamento do local, uso de flores já que a inserção de cores na escola é muito limitada, promovendo assim além de um espaço de convívio dos alunos um ambiente onde o ensino possa ser fomentado com o uso do pátio.

O pátio $\mathrm{C}$ onde se localizam os espaços esportivos, em todos os métodos foi apresentado como local preferido pelos alunos. É atualmente o único espaço com estrutura para atividades em grupo. Contudo foi notório durante o mapa comportamental que o uso da quadra ocorre de modo simultâneo por várias atividades pelo fato de não haverem outros locais para a realização, lembrando que a escola possui um terreno amplo e sem uso correto em sua maioria. Com isso, os alunos associam pontos positivos ao local. Nesta observação conclui-se a quadra de esportes tem grande importância dentro da 
escola, mas que ao seu redor, espaços poderiam ser criados a fim de as atividades fora da sala de aula pudessem ser dinamizadas e mais exploradas.

O Pátio D é composto de vários elementos como o espaço com bancos e arvores, apresentados aos alunos no método de mapeamento visual, este é uma tentativa de ambiente de convívio feita pela escola, contudo seu uso não ocorre pela falta de manutenção no local. A horta da escola é restrita aos cuidados de um funcionário, onde esta se apresenta sem uma estrutura adequada. Seu uso poderia ser explorado por questões pedagógicas com os alunos com o cultivo de frutas e hortaliças.

\section{Matriz de descobertas}

Diferente dos outros instrumentos, a matriz de descobertas não foi realizada durante a pesquisa de campo, mas sim na fase final da pesquisa. Com a finalização dos demais instrumentos, elaborou-se esta leitura crítica do resultados de modo sintetizado na tabela abaixo. 
TABELA 6: MATRIZ DE DESCOBERTAS

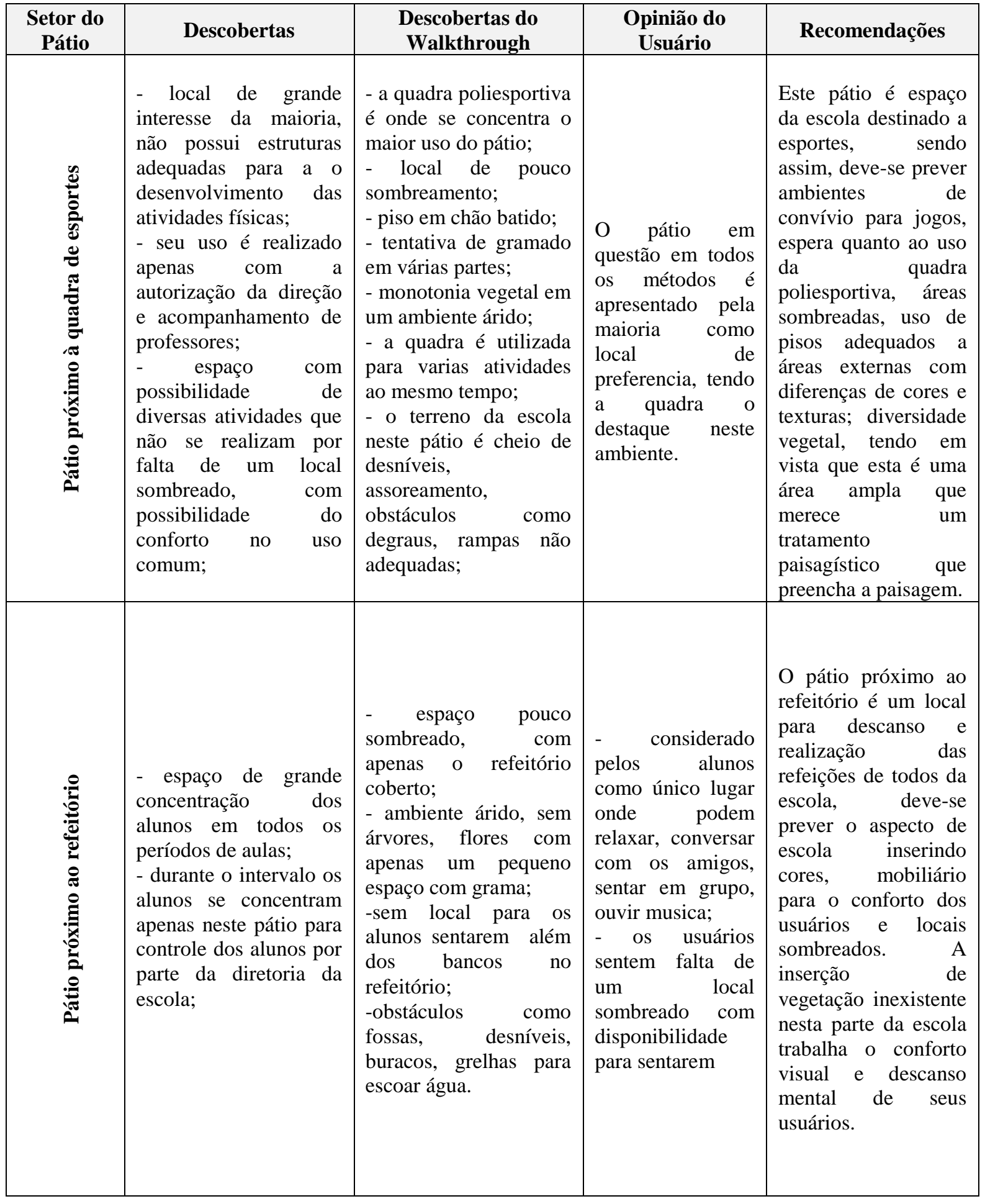




\begin{tabular}{|c|c|c|c|c|}
\hline $\begin{array}{l}\text { Setor do } \\
\text { Pátio }\end{array}$ & Descobertas & $\begin{array}{r}\text { Descobe } \\
\text { Walkth }\end{array}$ & $\begin{array}{l}\text { Opinião do } \\
\text { Usuário }\end{array}$ & Recomendações \\
\hline 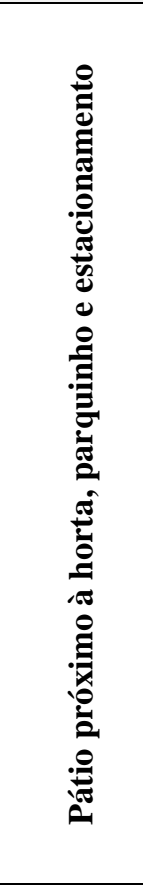 & $\begin{array}{l}\text { - a horta da escola é } \\
\text { muito bem cuidada por } \\
\text { um zelador, porém não } \\
\text { possui infraestrutura } \\
\text { para seu } \\
\text { desenvolvimento; } \\
\text { - o parquinho } \\
\text { conservado, está em } \\
\text { um ambiente } \\
\text { delimitado cujo uso } \\
\text { ocorre apenas com } \\
\text { autorização } \\
\text { acompanhamento de } \\
\text { professores; } \\
\text {-o estacionamento dos } \\
\text { professores é no } \\
\text { interior da escola, de } \\
\text { forma improvisada e } \\
\text { desordenada. }\end{array}$ & $\begin{array}{l}\text { - a falta de estrutura foi } \\
\text { o ponto observado } \\
\text { nesta localidade, com a } \\
\text { falta de estrutura para o } \\
\text { estacionamento dos } \\
\text { professores e horta. O } \\
\text { espaço existente é } \\
\text { suficiente para a } \\
\text { organização necessária } \\
\text { e melhor uso do pátio. }\end{array}$ & $\begin{array}{l}\text { - o parquinho da } \\
\text { escola tem grande } \\
\text { significado aos } \\
\text { alunos, devido ao } \\
\text { seu anseio lúdico } \\
\text { e ponto de } \\
\text { referencia para } \\
\text { qualquer criança } \\
\text { quando se fala em } \\
\text { escola; } \\
\text { - a horta da escola } \\
\text { é apresentada } \\
\text { pelos alunos } \\
\text { como um local } \\
\text { onde gostariam de } \\
\text { participar com } \\
\text { maior frequência } \\
\text { e até mesmo } \\
\text { aprender } r \\
\text { cultivar a } \\
\text { hortaliças; as }\end{array}$ & 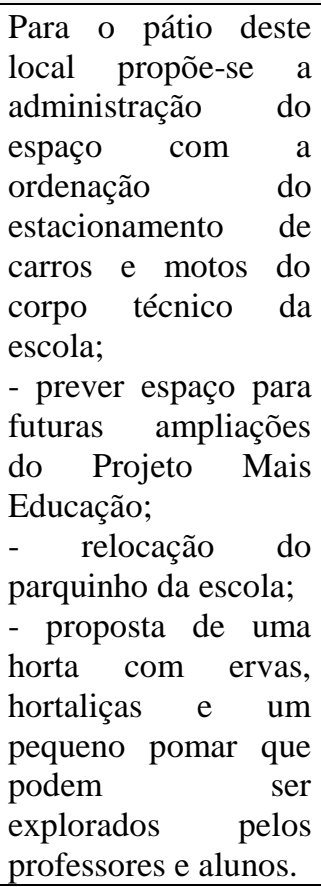 \\
\hline 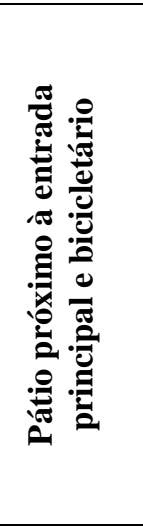 & $\begin{array}{l}\text { - espaço de uso } \\
\text { principalmente } \\
\text { corpo tócnico da } \\
\text { instituição sendo a } \\
\text { entrada e saída destes; } \\
\text { - é a entrada principal } \\
\text { da escola; } \\
\text { - o bicicletário está } \\
\text { bem posicionado, } \\
\text { próximo ao acesso de } \\
\text { entrada e saída dos } \\
\text { alunos. }\end{array}$ & $\begin{array}{l}\text { - iniciativa de } \\
\text { paisagismo realizado } \\
\text { de modo empírico; } \\
\text { - espaço de pouco uso } \\
\text { dos alunos; } \\
\text { - falta de calçamento na } \\
\text { frente da escola } \\
\text { ocasionando assim um } \\
\text { acesso precário neste } \\
\text { local. }\end{array}$ & $\begin{array}{l}-\quad \text { apresentado } \\
\text { pelos alunos } \\
\text { como local de uso } \\
\text { "proibido" tendo } \\
\text { acesso apenas ao } \\
\text { bicicletário; } \\
\text {-não apresentam } \\
\text { interesse em estar } \\
\text { neste pátio. }\end{array}$ & 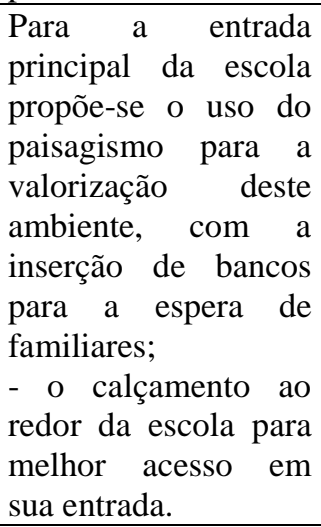 \\
\hline
\end{tabular}

Fonte: Elaborado pelos autores, 2013.

\section{Diretrizes}

Atendendo o objetivo geral da pesquisa, a aplicação dos instrumentos resultou na elaboração das diretrizes para a requalificação do pátio escolar. Para o desenvolvimento das diretrizes, a visão dos pesquisadores foi atrelada às opiniões dos usuários do ambiente, fazendo das diretrizes propostas passos para a efetivação do pátio escolar.

Como diretrizes tem-se:

- dinamizar a percepção dos espaços com o uso de texturas usando elementos como a vegetação no uso de cores, formas, texturas, aromas;

- áreas que possibilitem atividades em grupo; 
- possibilitar espaços para atividades pedagógicas;

- o uso de cores nos espaços;

- horta com possibilidade do cultivo e aprendizagem dos alunos;

- atender às necessidades de acessibilidade nas áreas externas.

\section{Considerações Finais}

Ao longo da presente pesquisa foi possível ressaltar a importância que a escola, quanto equipamento urbano, exerce nos dilemas sociais cotidianos. Muito, além disto, seu espaço físico, oriundo de uma história de transformações pedagógicas, sociais e físicas (nem sempre em consonância) é hoje palco de ações de descaso que convivem diariamente com o ato de ensino e aprendizagem.

É neste local que aos poucos o cidadão é formado, com seus valores de patriotismo, socialização, formação intelectual e ampliação de sua cultura. A negligência na concepção destes ambientes, por diversas vezes é causa de reações lamentáveis de depredação e deterioração do patrimônio público, devido ao fato de não dar possibilidade aos seus usuários de adquirirem o sentimento de pertencimento e acolhimento do local.

A escola, enquanto espaço físico esteve e sempre estará entrelaçada na formação e desenvolvimento pedagógico. A partir de sua configuração espacial, o sistema de ensino pode ser dinamizado. A sala de aula pode deixar seu aspecto de Grupo Escolar e fazer parte de um presente que corresponda às expectativas de formação então vigentes.

O pátio escolar pode ser um ambiente vivo, destinado a liberdade de todos, fonte de inspiração para o ensino e aprendizado, motivação de projetos pedagógicos, dentre tantas outras potencialidades fornecidas por este.

O objeto de estudo, o Centro Municipal de Ensino Gentila Susin Muraro, escolhido dentro do universo de escolas municipais da zona urbana, apresenta características que fomentam a necessidade de requalificação de sua área externa como: possibilidades de intervenções nas áreas livres sem uso e/ou mal uso em seu terreno, localização em uma região pobre com altos índices de depredação da escola, abertura e pré disposição por parte do corpo técnico em participar da pesquisa e concretiza-la posteriormente a partir de um projeto pedagógico.

A Avaliação Pós-Ocupação, ferramenta imprescindível para a interação usuário-ambiente no processo de projeto arquitetônico e requalificação do ambiente, foi utilizada por possibilitar a identificação das diretrizes que serviram como base para a requalificação do pátio do CME Gentila 
Susin Muraro, sendo os métodos de APO selecionados para aplicação de modo a atingir toda a população da escola.

As diretrizes obtidas demostram que o pátio pode ser potencializado de forma simples, atingindo as questões pedagógicas do ensino na escola.

Com este estudo, foi possível contribuir em diferentes áreas do conhecimento Arquitetura, Psicologia e Educação e acima disso fazer arquitetura pensada na melhoria da sociedade.

\section{Referências}

CERQUEIRA, Eufrosina de, A. Análise da Intervenção Ambiental de Baixo Custo em Escola da Rede Pública de Feira de Santana. UFRGS: Porto Alegre, 2001. Proposta de Dissertação de Mestrado - Programa de Pós-Graduação em Engenharia, Faculdade de Educação, Universidade Federal do Rio Grande do Sul. Orientador: Ph.D Miguel Aloysio Sattler.

KOWALTOWSKI, Doris C.C.K. Arquitetura escolar: o projeto do ambiente de ensino. $1^{\text {a }}$ ed. São Paulo: Oficina de Textos, 2011.

KOWALTOWSKI, Doris C.C.K; DELIBERADOR, Marcella Savioli. Os pátios e as áreas livres no processo de projeto de arquitetura escolar no estado de São Paulo. In: AZEVEDO, G. A. N. RHEINGANTZ, P.A. TÂNGARI, V.R. O lugar do pátio escolar no sistema de espaços livres: uso, forma e apropriação. $1^{\mathrm{a}}$ ed. Rio de Janeiro: Minister, 2011. p. 159-182.

KOWALTOWSKI, Doris C.C.K; PEREIRA, Paula Roberta Pizarro. Análises de Métodos de Avaliação de Projetos. Revista Gestão e Tecnologia de Projetos [ISSN: 19811543]. Recebido em: 30/01/2012 | Aprovado em: 28/05/2012. Volume 7, Número 1 | Maio, 2012.p. 3-19.

MACHADO, E.S. et al. Uma reflexão sobre métodos utilizados em apo: estudo de caso da creche Edson Luiz - RJ. In: XII Encontro Nacional de Tecnologia do Ambiente Construído (ENTAC): Geração de valor no ambiente construído: inovação e sustentabilidade, Fortaleza, Ceará, 2008.

MOREIRA, Alberto L. Princípios de engenharia de avaliações. São Paulo: Pini, 1984.

MATURANA R, H. \& VARELA, F. A árvore do conhecimento. Campinas:Psy II, 1995. . A ontologia da realidade. Belo Horizonte: UFMG, 2001-a.

Cognição, ciência e vida cotidiana. Belo Horizonte: UFMG, 2001-b.

NAMBU, Liliane Cristine; ORNSTEIN, Sheila, Walbe. O pátio nos ambientes para o aprendizado avaliação de edifícios escolares na região metropolitana de São Paulo. In: AZEVEDO, G. A. N. RHEINGANTZ, P.A. TÂNGARI, V.R. O lugar do pátio escolar no sistema de espaços livres: uso, forma e apropriação. $1^{\text {a }}$ ed. Rio de Janeiro: Minister, 2011. p. 91-106

NEPEC. Núcleo de extensão e pesquisas econômicas e contábeis. Perfil socioeconômico de Tangará da Serra. 2011. Disponível em: <http://www2.unemat.br/nepec/perfil_tangara>. Acesso em: 28 de nov. 2012.

OLIVEIRA, C. E. Famílias e Natureza: As relações entre as famílias e ambiente na colonização de Tangará da Serra - MT. Tangará da Serra: Gráfica Editora Sanches Ltda., 2004. ISBN 85-98446$01-7$. 
OLIVEIRA, C. E. Das Escolas Reunidas ao Grupo Escolar de Tangará da Serra: A Educação em Mato Grosso em Região de Colonização Recente - 1968 - 1975. In: X Jornada do HISTERDBR: História da Educação: VII Jornada do HISTEDBR - "O trabalho didático na história da educação", Campo Grande, 2007.

ORNSTEIN, Sheila. Avaliação Pós-Ocupação do Ambiente Construído. São Paulo: Stúdio Nobel, EDUSP, 1992.

PEREIRA, Paula Roberta Pizarro; KOWALTOWSKI, Doris C.C.K. Análise de Ferramentas de Avaliação de Projetos de Edificações Escolares. In: XI Encontro Nacional de Conforto do Ambiente Construído (ENCAC) e VII Encontro Latino Americano de Conforto no Ambiente Construído (ELACAC), Búzios, Rio de Janeiro, 2011.

RHEINGANTZ, Paulo Afonso et al. Walkthrough. Rio de Janeiro: [s.n.], 2007.

RICHARDSON, Roberto Jarry. Pesquisa social: métodos e técnicas. São Paulo: Atlas, 3 ed., 1999, $334 \mathrm{p}$

SEMEC - Secretaria Municipal de Educação e Cultura. Centros Municipais de Ensino. Disponível em: < http://semectangara.blogspot.com.br/search/label/Centros\%20Municipais\%20de\%20Ensino> Acesso em: 28 de nov. de 2013.

\section{Como citar este artigo (Formato ABNT):}

DALLASTRA, Mauricio; FERNANDES, Morgana Alves de Jesus; BRESCOVIT, Luiz Eduardo; COSTA, Bruna Lopes. Avaliação Pós-Ocupação de Edificação Escolar: Proposta de Diretrizes para a Requalificação do Pátio Escolar. Id on Line Revista Multidisciplinar e de Psicologia, 2018, vol.12, n.39, p.612-657. ISSN: 1981-1179.

Recebido: 16.01 .2018

Aceito: 18.01.2018 